\title{
In vitro and in vivo effects of flubendiamide and copper on cyto- genotoxicity, oxidative stress and spleen histology of rats and its modulation by resveratrol, catechin, curcumin and a- tocopherol
}

Rajesh Mandil ${ }^{*}$, Atul Prakash², Anu Rahal ${ }^{3}$, S. P. Singh ${ }^{4}$, Deepak Sharma ${ }^{4}$, Rahul Kumar ${ }^{5}$ and Satish Kumar Garg ${ }^{2}$

\begin{abstract}
Background: Living organisms are frequently exposed to more than one xenobiotic at a time either by ingestion of contaminated food/fodder or due to house-hold practices, occupational hazards or through environment. These xenobiotics interact individually or in combination with biological systems and act as carcinogen or produce other toxic effects including reproductive and degenerative diseases. Present study was aimed to investigate the cyto-genotoxic effects of flubendiamide and copper and ameliorative potential of certain natural phyotconstituent antioxidants.

Method: In vitro cytogenotoxic effects were evaluated by employing battery of assays including Propidium iodide staining, Tunel assay, Micronuclei, DNA fragmentation and Comet assay on isolated splenocytes and their prevention by resveratrol (5 and $10 \mu \mathrm{M})$, catechin $(10$ and $20 \mu \mathrm{M})$, curcumin $(5$ and $10 \mu \mathrm{M})$ and a-tocopherol $(5,10$ and $20 \mu \mathrm{M})$. In vivo study was also undertaken daily oral administration of flubendiamide $(200 \mathrm{mg} / \mathrm{kg})$ or copper $(33 \mathrm{mg} / \mathrm{kg})$ and both these in combination, and also all these concurrently with of a-tocopherol to Wistar rats for 90 days.

Results: Flubendiamide and copper produced concentration-dependent cytotoxic effects on splenocytes and at median lethal concentrations, flubendiamide $(40 \mu \mathrm{M})$ and copper $(40 \mu \mathrm{M})$ respectively produced 71 and $81 \%$ nonviable cells, higher number of Tunel+ve apoptotic cells, 7.86 and $9.16 \%$ micronucleus and 22.90 and 29.59 comets/100 cells and DNA fragmentation. In vivo study revealed significant $(P<0.05)$ increase in level of lipid peroxidation $(L P O)$ and decrease in glutathione peroxidase (GPx), glutathione-S-transferase (GST) and superoxide dismutase (SOD) activities in groups exposed to flubendiamide or copper alone or both these in combination. Histopathological examination of rat spleens revealed depletion of lymphoid tissue, separation of splenocytes and rarification in splenic parenchyma of xenobiotic(s) treated groups.

(Continued on next page)
\end{abstract}

\footnotetext{
* Correspondence: rajesh_mandil@rediffmail.com

'Department of Veterinary Pharmacology and Toxicology, College of Veterinary and Animal Sciences, Sardar Vallabhbhai Patel University of Agriculture and Tecahnology, 250110, Meerut, India

Full list of author information is available at the end of the article
}

(c) The Author(s). 2020 Open Access This article is licensed under a Creative Commons Attribution 4.0 International License, which permits use, sharing, adaptation, distribution and reproduction in any medium or format, as long as you give appropriate credit to the original author(s) and the source, provide a link to the Creative Commons licence, and indicate if changes were made. The images or other third party material in this article are included in the article's Creative Commons licence, unless indicated otherwise in a credit line to the material. If material is not included in the article's Creative Commons licence and your intended use is not permitted by statutory regulation or exceeds the permitted use, you will need to obtain permission directly from the copyright holder. To view a copy of this licence, visit http://creativecommons.org/licenses/by/4.0/ The Creative Commons Public Domain Dedication waiver (http://creativecommons.org/publicdomain/zero/1.0/) applies to the data made available in this article, unless otherwise stated in a credit line to the data. 


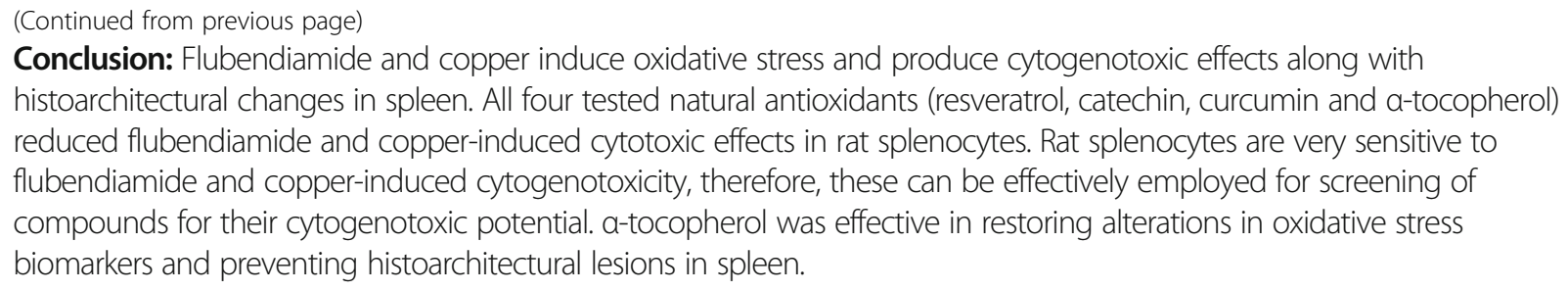

Keywords: Flubendiamide, Copper, Splenocytes, Cyto-genotoxicity, Oxidative stress

\section{Background}

Last few decades toxicological research has revealed that immune system is the potential target for xenobioticsinduced adverse effects due to exposure to environmental pollutants, indiscriminate use of agrochemicals, metals, drugs, other chemicals and their metabolites. Therefore, the present study was undertaken to investigate the cytogenotoxic potential of flubendiamide and copper in rat splenocytes primary cell culture following in vitro exposure. In vivo effect of these xenobiotics on oxidative stress biomarkers and histopathological changes in rat spleen were also studied. Ameliorative potential of $\alpha$-tocopherol and other plants-based antioxidants against the adverse effects of these xenobiotics was also evaluated. For in vivo study, Wistar rats were orally exposed to flubendiamide or copper alone, both these in combination, and also along with $\alpha$-tocopherol for 90 days.

Flubendiamide is a comparatively new insecticide and selectively acts on insects ryanodine receptors (RyR). It possesses favourable toxicological profile due to its higher (> $2000 \mathrm{mg} / \mathrm{kg}$ ) oral and dermal $\mathrm{LD}^{50}$ values in rats. Being comparatively safe, it is being widely used on large number of crops which include fruits, vegetable crops and nuts to control insects. Therefore, human beings and animals are also being indiscriminately exposed to flubendiamide through direct and indirect routes. Genotoxicity is the primary risk factor associated with long-term exposure to environmental pollutants including insecticides and metals. Flubendiamide does not have genotoxic effects on bone marrow cells [16]. But there are reports that exposure to certain xenobiotics, either individually or in combination, may result in gene mutation, chromosomal aberrations and DNA damage [7-9].

Copper, being a micronutrient, is essential for life of humans and animals and is required in minute concentrations for functioning of several metalloenzymes [1012]. It also possesses fungicidal, molluscicidal and weedicidal activities and is employed for control of bacterial and fungal diseases of fruits, vegetables, nuts and field crops, algae in domestic lakes and ponds and in gardening as powder and spray [13, 14]. In India, copper also enters in human body through drinking water, and inhalation of copper dust and fumes [15]. But it is toxic when present in the body in excess [10].

Environmental pollutants increase oxidative stress [16] and dietary antioxidants prevent free radicals induced tissue damage by preventing formation of radicals, scavenging them, or by promoting their decomposition [17-19]. Several natural food-derived components have received great attention in recent years as nutraceuticals due to their promising biological activities. $\alpha$-tocopherol $(\alpha$ $\mathrm{TOH}$ ) is the major lipid soluble natural form of vitamin $\mathrm{E}$ and possesses antioxidant property. It protects cellular membrane and lipoproteins from peroxidation by reacting with lipid radicals produced in lipid peroxidation chain reaction [20-22]. Green tea is very rich in phenolic compounds including catechin and epigallocatechin gallate (EGCG) [23]. These are powerful antioxidant, inhibit apoptosis by inhibiting caspase 3 activity thereby preventing expression of proapoptotic (Bax, Bad and Mdm2) and antiapoptotic genes $(\mathrm{Bcl}-2, \mathrm{Bcl}-\mathrm{w}$ and $\mathrm{Bcl}-\mathrm{xL})$ to protect SH-SY5Y cells from 6-OHDA-induced apoptosis [24-26] and EGCG is cancer chemopreventive also [27]. Curcumin is the main coloring agent of turmeric, used as a spice in India, and possesses number of promising pharmacological activities including antioxidant [28-31] and DNA protective effect against arsenic, fluoride and chlorpyriphos [32-34]. Phytoallexin resveratrol, found in the skin of grapes, possesses the potential to inhibit cancer initiation, promotion and progression, and inhibits TNF $\alpha-$ induced reactive oxygen intermediate generation [35-37].

In view of the sparse information on in vitro cytogenotoxicity potential and in vivo adverse effects of flubendiamide in mammals, and conflicting reports on genotoxic effects of copper, the present study was undertaken. We also evaluated the ameliorative potential of certain natural phyotconstituent antioxidants against these xenobiotics to explore their therapeutic and prophylactic use.

\section{Methods}

\section{Experimental animals and chemicals}

Present study was undertaken on Wistar rats, which were procured from Laboratory Animal Resource Section, Indian Veterinary Research Institute, Izatnagar, India and maintained under standard managemental 
conditions in the Departmental Experimental Animal House. Animals had free access to pelleted feed (Ashirwad Industries, Chandigarh) and clean and deionized drinking water. Daily light and dark cycle of $12 \mathrm{~h}$ was ensured. Before start of the experiment, an acclimatization period of 15 days was allowed. Whole study was carried out in two phases: Phase I - in vitro apoptosis studies while Phase II included only in vivo studies.

The study was approved by the Institutional Animal Ethics Committee (IAEC; 79 IAEC/13). Flubendiamide, dexamethasone, resveratrol, catechin, curcumin, and $\alpha-$ tocopherol were procured from Sigma-Aldrich (USA) while copper sulphate from Sd Fine Chemical Ltd.

\section{Phase I- in vitro study}

Twenty adult male Wistar rats weighing $80-100 \mathrm{~g}$ were used for in vitro cyto-genotoxicity study on primary cell culture of isolated rat splenocytes.

\section{Isolation of splenocytes}

Rats were sacrificed by cervical dislocation and spleen was aseptically removed and quickly disintegrated into many pieces. Vigorous pipetting of meshed tissue was done with the help of $10 \mathrm{ml}$ glass pipette to break the minced tissue and these cells were transferred to 15 $\mathrm{ml}$ test tubes containing chilled PBS and allowed to stand on ice for $15 \mathrm{~min}$. Top $12 \mathrm{ml}$ of suspension was collected into another centrifuge tube and cells were pelleted by centrifugation at $1500 \mathrm{rpm}$ for $10 \mathrm{~min}$. Cells pellet was re-suspended in PBS and centrifuged again at $1500 \mathrm{rpm}$ for $10 \mathrm{~min}$. The supernatant was discarded and pellet was treated with $5 \mathrm{ml}$ of $\mathrm{RBC}$ lysis buffer $\left(4.15 \mathrm{~g} \mathrm{NH}_{4} \mathrm{Cl} ; 0.5 \mathrm{~g} \mathrm{NaHCO} ; 0.0186 \mathrm{~g}\right.$ $\mathrm{Na}_{2}$-EDTA; $200 \mathrm{ml} \mathrm{DW}$ ) and kept for $10 \mathrm{~min}$ in ice and centrifuged at $1500 \mathrm{rpm}$ for $10 \mathrm{~min}$. Then the pellet was given two washings with PBS at $1500 \mathrm{rpm}$ for $10 \mathrm{~min}$. The pellet was re-suspended in $1 \mathrm{ml}$ of Roswell Park Memorial Institute (RPMI-1640; SigmaAldrich) medium with $10 \%$ foetal calf serum (SigmaAldrich). Viability count was done using $0.1 \%$ trypan blue exclusion test and the cells density was adjusted to obtain $10^{6}$ cells $/ \mathrm{ml}[38]$.

\section{Median lethal concentrations}

Isolated splenocytes were seeded in 24 well culture plates containing $10^{6}$ cells $/ \mathrm{ml}$ in $10 \%$ RPMI with foetal calf serum. Different concentrations of flubendiamide and copper i.e. 1.0, 2.5, 5, 7.5, 10, 15, 20, 40, 60,80 and $100 \mu \mathrm{M}$ were used. Culture plates were incubated for $12 \mathrm{~h}$ in $\mathrm{CO}_{2}$ incubator (New Brunswick Scientific, USA) at $37{ }^{\circ} \mathrm{C}$ with $5 \% \mathrm{CO}_{2}$. After incubation, samples were collected in $1.5 \mathrm{ml}$ eppendorf tubes and centrifuged at $3200 \mathrm{rpm}$ for $10 \mathrm{~min}$. Supernatant was discarded and the pellet was dissolved in $0.5 \mathrm{ml}$
PBS. Propidium iodide (Sigma) was added at $1 \mu \mathrm{g} / \mathrm{ml}$ concentration to cells and incubated for another 15 min in dark at room temperature. Cells were observed under fluorescent microscope (Microscan 20 PFM, Nitco) under green filter to determine the approximate concentrations of test xenobiotics at which almost 50\% dead splenocytes were observed. Calculation of the LC50 value of flubendiamide and copper was done by subjecting the data (concentrations used versus \% cell dead) of Table 1 to "Probit Analysis method" using "Graph Pad Prism software" and by plotting the log values of the concentrations of xenobiotics used against log values of the per cent cells dead. Further we interpolated the respective log values of the xenobiotics (copper and flubendiamide) at which $50 \%$ of the cells are expected to be dead, and then the antilog values of these log values were calculated. It is apparent that the interpolated LC50 value for copper was $38.90 \mu \mathrm{M}$ and for flubendiamide, it was $37.23 \mu \mathrm{M}$. Both these values are very close to $40 \mu \mathrm{M}$ and considered as median lethal concentration of flubendiamide and copper and used for further studies.

\section{Viability of splenocytes}

Freshly collected splenocytes $\left(10^{6}\right.$ cells $\left./ \mathrm{ml}\right)$ were exposed to median lethal concentrations of flubendiamide and copper alone, and also along with the antioxidants- resveratrol $(5$ and $10 \mu \mathrm{M})$, curcumin $(5$ and $10 \mu \mathrm{M})$, catechin $(10$ and $20 \mu \mathrm{M})$ and $\alpha$-tocopherol $(5,10$ and $20 \mu \mathrm{M})$. Solutions of resveratrol, catechin, curcumin, $\alpha$-tocopherol, flubendiamide, copper sulphate and dexamethasone were prepared in dimethyl sulphoxide (DMSO). Culture plates were incubated for $12 \mathrm{~h}$ in $\mathrm{CO}_{2}$ incubator at $37^{\circ} \mathrm{C}$ with $5 \% \mathrm{CO}_{2}$ and further processed as described above to determine the number of nonviable cells.

\section{TUNEL assay}

After exposure of splenocytes to median lethal concentrations of flubendiamide $(40 \mu \mathrm{M})$ and copper $(40 \mu \mathrm{M})$ for $12 \mathrm{~h}$, these samples were further processed for determination of apoptosis as per the protocol described in TUNEL Assay Kit (Invitrogen, USA; Ref. No. A35126). Apoptotic cells, which underwent extensive DNA degradation during late stages of apoptosis, were examined under blue filter of fluorescent microscope. Cells which fluoresced brightly were considered as apoptotic.

\section{Genotoxicity assays (micronucleus, DNA fragmentation and comet) \\ Micronucleus assay}

Flubendiamide and copper genotoxicity potential was assessed by micronuclei assay by using the isolated splenocytes [39]. $10^{6}$ cells $/ \mathrm{ml}$ were incubated with 
Table 1 Effect of different concentrations of flubendiamide and copper on per cent viability of rat splenocytes following their in vitro exposure to these xenobiotics

\begin{tabular}{ll}
\hline Treatment & \% Dead Splenocytes \\
\hline Control & $4.93 \pm 0.67$ \\
Vehicle control (DMSO) $50 \mu \mathrm{l}$ & $7.46 \pm 0.83$ \\
$1.0 \mu \mathrm{M}$ Flubendiamide & $12.98 \pm 1.92$ \\
$2.5 \mu \mathrm{M}$ Flubendiamide & $15.13 \pm 1.87$ \\
$5.0 \mu \mathrm{M}$ Flubendiamide & $22.18 \pm 1.67$ \\
$7.5 \mu \mathrm{M}$ Flubendiamide & $24.28 \pm 2.24$ \\
$10 \mu \mathrm{M}$ Flubendiamide & $28.09 \pm 1.33$ \\
$15 \mu \mathrm{M}$ Flubendiamide & $29.76 \pm 1.55$ \\
$20 \mu \mathrm{M}$ Flubendiamide & $32.32 \pm 1.32$ \\
$40 \mu \mathrm{M}$ Flubendiamide & $45.42 \pm 2.50$ \\
$60 \mu \mathrm{M}$ Flubendiamide & $67.89 \pm 3.14$ \\
$80 \mu \mathrm{M}$ Flubendiamide & $88.81 \pm 5.62$ \\
$1.0 \mu \mathrm{M}$ Copper & $6.45 \pm 3.04$ \\
$2.5 \mu \mathrm{M}$ Copper & $10.34 \pm 1.63$ \\
$5.0 \mu \mathrm{M}$ Copper & $13.88 \pm 1.39$ \\
$7.5 \mu \mathrm{M}$ Copper & $16.66 \pm 1.92$ \\
$10 \mu \mathrm{M}$ Copper & $26.08 \pm 4.73$ \\
$15 \mu \mathrm{M}$ Copper & $28.39 \pm 1.74$ \\
$20 \mu \mathrm{M}$ Copper & $34.95 \pm 5.87$ \\
$40 \mu \mathrm{M}$ Copper & $51.09 \pm 2.01$ \\
$60 \mu \mathrm{M}$ Copper & $61.11 \pm 2.03$ \\
$80 \mu \mathrm{M}$ Copper & $76.68 \pm 1.71$ \\
\hline
\end{tabular}

Data presented are Mean \pm SEM of three observations

flubendiamide $(40 \mu \mathrm{M})$ and copper $(40 \mu \mathrm{M})$ alone and with different $\mu \mathrm{M}$ concentrations of resveratrol, catechin, curcumin and $\alpha$-tocopherol and incubated for $12 \mathrm{~h}$ in $\mathrm{CO}_{2}$ incubator. After incubation, samples were collected in $1.5 \mathrm{ml}$ eppendorf tubes and centrifuged at $3200 \mathrm{rpm}$ for $10 \mathrm{~min}$. Supernatants were discarded and the pellets were dissolved in $1.0 \mathrm{ml}$ of Hank's balanced salt solution (HBSS) having pH 7.2 and centrifuged again for $10 \mathrm{~min}$ at $3200 \mathrm{rpm}$. Supernatant was removed and cells in suspension were mixed carefully in $100 \mu \mathrm{l}$ of HBSS. A drop of cell suspension was taken on grease-free clean glass slide and smeared. The smear was air-dried and fixed with absolute methanol (100\%) for $5 \mathrm{~min}$ and stained with acridine orange for $1 \mathrm{~min}$ at room temperature. The slide was rinsed in Sorensen's buffer (pH 6.8) and kept for at least 3 min and this step was repeated three times. Slides were examined on the same day and 1000 cells (both mononuclear and binucleated) per slide were scored under green filter of the fluorescent microscope to determine the frequency of micronuclei formation.

\section{DNA fragmentation assay}

DNA ladder assay was performed according to phenolchloroform-DNA isolation protocol [40]. After incubation of $5 \times 10^{6}$ cells each with flubendiamide or copper alone and with antioxidants, as mentioned in micronuclei assay method, the cells were collected in $1.5 \mathrm{ml}$ of eppendorf tubes and centrifuged at $3200 \mathrm{rpm}$ for $10 \mathrm{~min}$ at $4{ }^{\circ} \mathrm{C}$. The cells pellet was washed with PBS having $\mathrm{pH}$ 7.2, mixed with DNA extraction buffer ( $500 \mu \mathrm{l} /$ tube) and kept in water bath for 1.0 $\mathrm{h}$ at $37^{\circ} \mathrm{C} .10 \%$ SDS was added $(20 \mu \mathrm{l} / \mathrm{ml})$ to the cell suspension and tubes were gently mixed by inverting the tubes. Contents of the tubes appearing viscous indicated lysis of splenocytes. Proteinase K ( $15 \mu \mathrm{l}$ of $20 \mathrm{mg}$ Proteinase K/ml of buffer) was added to each tube in two pulses i.e. half the requirement was added to tube in the 1st pulse and mixed gently and kept in water bath at $50{ }^{\circ} \mathrm{C}$. After $3-4 \mathrm{~h}$, a second pulse of the remaining amount of proteinase $\mathrm{K}$ was added. Tubes were incubated at $50{ }^{\circ} \mathrm{C}$ overnight. Next day morning, equal amount of equilibrated phenol (Tris saturated phenol $\mathrm{pH}>7.8$ ) was added to each tube and mixed by gently inverting the tubes for $15 \mathrm{~min}$ till light coffee coloured uniform solution was formed and centrifuged at $3400 \mathrm{rpm}$ for $15 \mathrm{~min}$. The upper aqueous phase containing DNA was transferred into fresh $1.5 \mathrm{ml}$ clean eppendorf tube. Similar extraction was done (as in the above step) once with equal volume of phenol: chloroform: isoamyl alcohol (25:24:1) and with chloroform: isoamyl alcohol (24:1). To obtain the final aqueous phase, double the volume of chilled $\left(-20^{\circ} \mathrm{C}\right)$ ethanol was added. Tubes were mixed gently by inversion and kept at room temperature to allow precipitation of DNA. DNA pellet was washed twice with $500 \mu \mathrm{l}$ of $70 \%$ ethanol and eppendorf tube was centrifuged at $10000 \mathrm{rpm}$ for 10 $\mathrm{min}$ at room temperature. Finally $70 \%$ ethanol was discarded and DNA pellet was air dried by inverting tube on blotting paper so that last traces of ethanol were removed. However, it was ensured that pellet did not over-dry so to enable an easy dissolution in the following step. Approximately $50 \mu \mathrm{l}$ of tris-EDTA buffer (TE) was added and kept in water bath at $60{ }^{\circ} \mathrm{C}$ for $2 \mathrm{~h}$ to inactivate DNAse and other enzymes. Eppendorf was stored at $4{ }^{\circ} \mathrm{C}$ for a week so that DNA was dissolved. DNA concentration and its purity was determined spectrophotmetrically by Biophotometer plus (Eppendorf) at 260 and 280 OD. Integrity of the DNA was examined in agarose gel (1.0\%) electrophoresis and visualized under UV light in gel documentation system after staining with ethidium bromide.

\section{Comet assay}

Single splenocyte cells were isolated from spleen after cervical dislocation and viability checked by Trypan blue exclusion test. $5 \times 10^{6}$ cells/well were kept for culturing and treated with flubendiamide and copper $(40 \mu \mathrm{M} /$ well $)$ alone and with different micromolar concentrations of resveratrol, catechin, curcumin and $\alpha$-tocopherol. After 
incubation of $12 \mathrm{~h}$ in $\mathrm{CO}_{2}$ incubator, cells were collected in $1.5 \mathrm{ml}$ eppendorf tubes and centrifuged at $3200 \mathrm{rpm}$ for $10 \mathrm{~min}$ at $4{ }^{\circ} \mathrm{C}$. Supernatant was discarded and the pellet was washed with PBS ( $\mathrm{pH}$ 7.2). Comet assay was performed using the standard method with normal (NMA) and low melting agarsoe (LMPA) [41].

Briefly, slides were dipped in methanol and heated over blue flame to remove the grease, dust and oil. 1.5\% NMA (Sigma-Aldrich) and 0.5\% LMPA (Sigma-Aldrich) were prepared in PBS. LMP agarose was kept in water bath at $40^{\circ} \mathrm{C}$ to cool and stabilize while NMA agarose was kept at $100^{\circ} \mathrm{C}$. First layer of agarose on the slides was prepared by dipping conventional pre-cleaned slide for few seconds in $100 \mathrm{ml}$ wide mouth beaker containing $1.5 \%$ NMA up to one-third area and gently removed. Underside of the slide was wiped to remove excess agarose and allowed to dry in a tray. Slides were generally prepared a day earlier. Splenocyte cell pellets were uniformly mixed with $100 \mu \mathrm{l}$ of $0.5 \%$ LMPA and poured carefully on the first agarose layer and immediately covered with a full length cover slip. Slides were kept on ice-pack for $15-20 \mathrm{~min}$ to allow for the 2nd agarose layer to solidify. After solidification, the cover slip was removed and the slide was kept in a coupling jar containing freshly prepared lysis solution (1 ml-Triton X100 and $10 \mathrm{ml}$ DMSO was added to $89 \mathrm{ml}$ stock lysing solution containing NaCl-36.52 g; EDTA disodium salt$9.3 \mathrm{~g}$; Trizma- $0.3 \mathrm{~g}$; NaOH-2 g- For $250 \mathrm{ml}$ ) at $4{ }^{\circ} \mathrm{C}$ overnight. Next day, the slide was removed from lysis solution and kept for $30 \mathrm{~min}$ in freshly prepared electrophoretic buffer so as to cause unwinding of DNA and expression of alkali-labile sites. Slide was run in horizontal electrophoresis (Bio Rad) chamber with the same electrophoresis buffer $(\mathrm{pH}>13)$ at $25 \mathrm{~V}$ and 300 $\mathrm{mA}$ for $1 \mathrm{~h}$. After running in electrophoresis chamber, the slide was gently removed and placed horizontally in a tray and covered with neutralizing buffer for 5 min and then decanted it; the same step was repeated three times to remove alkali and detergent. This step was critical to bring down the $\mathrm{pH}$ from 13 to 7.5 . After neutralization, slides were stained by placing 3-4 drops of $100 \mu \mathrm{l}$ working ethidium bromide solution at equal distance and immediately covered with cover slip. Slides were examined under fluorescent microscope, individual cell/comets were observed and images were captured at $40 \mathrm{X}$ magnification using green filter and duplicate slides per treatment were observed. At least 50 cells from each slide were scored and a total of 100 cells/treatment was scored to get the reproducible data.

\section{Phase II-in vivo chronic toxicity study}

Fifty four adult male Wistar rats weighing between 130 and $150 \mathrm{~g}$ were divided in nine groups of six animals each. Animals of six groups (IV to IX) were orally treated on daily basis with copper (33 mg/kg; group IV), flubendiamide $(200 \mathrm{mg} / \mathrm{kg}$; group V) or combination of both these (group VI), and $\alpha$-tocopherol $(100 \mathrm{mg} / \mathrm{kg}$ ) along with these xenobiotics singly (group VII and VIII) or both these in combination (group IX) for 90 days. Groups I and II served as negative and vehicle controls (corn oil), respectively while rats of group III were administered only $\alpha$-tocopherol $(100 \mathrm{mg} / \mathrm{kg})$. Solutions of copper sulphate and flubendiamide (FAME ${ }^{\circ}$, Bayer) were prepared in deionized water while $\alpha$-tocopherol was dissolved in corn oil. Doses of flubendiamide and copper were $1 / 10$ th of the $\mathrm{LD}_{50}$. At the end of exposure period, rats were humanely sacrificed by cervical dislocation and their spleen was collected and blotted with tissue paper. It was then used to determine its levels of different oxidative stress related parameters such as lipid peroxidation (LPO), reduced glutathione (GSH), catalase (CAT), superoxide dismutase (SOD), glutathione-S-transferase (GST) and glutathione peroxidase (GPx), along with total protein content in splenic tissue using UV- VIS spectrophotometeric methods [42-48]. $200 \mathrm{mg}$ of the spleen sample was weighed and transferred in $2 \mathrm{ml}$ of chilled saline. The same weight of the spleen sample was separately taken in $2 \mathrm{ml}$ of $0.02 \mathrm{M}$ EDTA for GSH estimation. Tissue homogenates were prepared by using tissue homogenizer (Heidolph) under cold conditions and centrifuged for $10 \mathrm{~min}$ at $3000 \mathrm{rpm}$. The supernatant was used for estimation of different oxidative stress biomarkers. Lipid peroxidation (LPO) and reduced glutathione (GSH) were assayed immediately after tissue collection.

A small piece of the spleen tissue was collected in 10\% formaldehyde saline solution and processed for preparation of paraffin blocks as per the method described by [49]. Tissue sections of $5-6 \mu \mathrm{m}$ thickness were cut using a microtome (Leica, Germany) and stained with haematoxylin and eosin. Microscopic slides were examined under light microscope to observe the histoarchitecture changes in spleen.

\section{Statistical analysis of data}

Data of the in vitro study has been presented as Mean \pm SEM of the three observations in each treatment group in Tables 1 and 2. Table 3 presents the Mean \pm SEM data of in vivo study. Effects of different in vitro treatments were compared between the control and xenobiotics alone-treated groups, and also between the xenobiotics alone and those treated concurrently with antioxidants. Statistically significant differences between the different treatment groups observed in in vivo study were determined using oneway ANOVA followed by Tukey's multiple post-hoc test with the help of SPSS $^{\circ} 16$ software. Significant difference was considered at $P<0.05$. 
Table 2 Effect of median lethal concentrations of flubendiamide and copper alone and in the presence of different concentrations of resveratrol, catechin, curcumin and a-tocopherol on viability, micronuclei and comet formation in rat splenocytes following their in vitro exposure

\begin{tabular}{|c|c|c|c|}
\hline Treatments & ${ }^{\mathrm{a}}$ Nonviable cells (\%) & ${ }^{\mathrm{a}}$ Micronuclei (\%) & No. of Comet/ 100 cells (\%) \\
\hline Control & $5.41 \pm 0.33$ & $0.96 \pm 0.08$ & $3.09 \pm 0.31$ \\
\hline DMSO (50 $\mu \mathrm{l})$ & $8.59 \pm 0.88$ & $1.36 \pm 0.08$ & $4.58 \pm 0.28$ \\
\hline Dexamethasone $(20 \mu \mathrm{M})$ & - & $7.60 \pm 0.20$ & $27.69 \pm 0.87$ \\
\hline Flubendiamide $(40 \mu \mathrm{M})$ & $71.88 \pm 2.90$ & $7.86 \pm 0.17$ & $22.90 \pm 0.90$ \\
\hline Resveratrol $(5 \mu \mathrm{M})+$ Flubendiamide $(40 \mu \mathrm{M})$ & $50.00 \pm 1.85$ & $1.20 \pm 0.17$ & $20.15 \pm 1.91$ \\
\hline Resveratrol $(10 \mu \mathrm{M})+$ Flubendiamide $(40 \mu \mathrm{M})$ & $24.36 \pm 0.88$ & $1.10 \pm 0.05$ & $15.44 \pm 1.47$ \\
\hline Catechin $(10 \mu \mathrm{M})+$ Flubendiamide $(40 \mu \mathrm{M})$ & $53.66 \pm 1.76$ & $1.43 \pm 0.24$ & $14.80 \pm 1.25$ \\
\hline Catechin $(20 \mu \mathrm{M})+$ Flubendiamide $(40 \mu \mathrm{M})$ & $52.46 \pm 2.33$ & $1.33 \pm 0.08$ & $12.64 \pm 0.57$ \\
\hline Curcumin $(5 \mu \mathrm{M})+$ Flubendiamide $(40 \mu \mathrm{M})$ & $56.25 \pm 3.05$ & $3.13 \pm 0.12$ & $7.58 \pm 0.89$ \\
\hline Curcumin $(10 \mu \mathrm{M})+$ Flubendiamide $(40 \mu \mathrm{M})$ & $38.24 \pm 3.18$ & $1.40 \pm 0.15$ & $7.20 \pm 0.32$ \\
\hline a-tocopherol $(5 \mu \mathrm{M})+$ Flubendiamide $(40 \mu \mathrm{M})$ & $55.00 \pm 0.33$ & $2.10 \pm 0.40$ & $11.56 \pm 0.33$ \\
\hline a-tocopherol $(10 \mu \mathrm{M})+$ Flubendiamide $(40 \mu \mathrm{M})$ & $40.26 \pm 2.02$ & $1.93 \pm 0.29$ & $6.96 \pm 0.30$ \\
\hline a-tocopherol $(20 \mu \mathrm{M})+$ Flubendiamide $(40 \mu \mathrm{M})$ & $17.65 \pm 0.57$ & $3.30 \pm 0.26$ & $4.89 \pm 0.33$ \\
\hline Copper $(40 \mu \mathrm{M})$ & $81.11 \pm 6.06$ & $9.16 \pm 0.21$ & $29.59 \pm 1.76$ \\
\hline Resveratrol $(5 \mu \mathrm{M})+$ Copper $(40 \mu \mathrm{M})$ & $76.54 \pm 4.84$ & $4.80 \pm 0.20$ & $25.33 \pm 0.47$ \\
\hline Resveratrol $(10 \mu \mathrm{M})+$ Copper $(40 \mu \mathrm{M})$ & $30.43 \pm 4.04$ & $1.90 \pm 0.32$ & $9.69 \pm 0.66$ \\
\hline Catechin $(10 \mu \mathrm{M})+$ Copper $(40 \mu \mathrm{M})$ & $72.13 \pm 3.71$ & $5.20 \pm 0.20$ & $15.12 \pm 0.32$ \\
\hline Catechin $(20 \mu \mathrm{M})+$ Copper $(40 \mu \mathrm{M})$ & $65.82 \pm 1.41$ & $2.10 \pm 0.36$ & $12.41 \pm 1.20$ \\
\hline Curcumin $(5 \mu \mathrm{M})+$ Copper $(40 \mu \mathrm{M})$ & $64.18 \pm 3.84$ & $3.47 \pm 0.14$ & $16.80 \pm 0.87$ \\
\hline Curcumin $(10 \mu \mathrm{M})+$ Copper $(40 \mu \mathrm{M})$ & $59.68 \pm 4.33$ & $2.63 \pm 0.21$ & $12.71 \pm 1.32$ \\
\hline a-tocopherol $(5 \mu \mathrm{M})+$ Copper $(40 \mu \mathrm{M})$ & $59.72 \pm 5.0$ & $3.33 \pm 0.24$ & $10.33 \pm 1.20$ \\
\hline a-tocopherol(10 $\mu \mathrm{M})+$ Copper $(40 \mu \mathrm{M})$ & $54.73 \pm 4.91$ & $1.93 \pm 0.18$ & $15.20 \pm 1.45$ \\
\hline a- tocopherol $(20 \mu \mathrm{M})+$ Copper $(40 \mu \mathrm{M})$ & $51.06 \pm 4.18$ & $3.16 \pm 0.26$ & $10.61 \pm 0.66$ \\
\hline
\end{tabular}

${ }^{\mathrm{a}}$ Data presented are Mean \pm SEM of three observations

\section{Results}

\section{Phase I- in vitro study}

\section{Median lethal concentrations}

Data on in vitro effect of different concentrations of flubendiamide $(1.0-80 \mu \mathrm{M})$ and copper $(1.0-80 \mu \mathrm{M})$ on rats splenocytes revealed concentration-dependent lethal effect of these xenobiotics. There was dose-dependent increase in percentage of the nonviable splenocytes and nearly $50 \%$ nonviable splenocytes were observed between $40 \mu \mathrm{M}$ and $60 \mu \mathrm{M}$ concentrations of these xenobiotics (Table 1). Therefore, $40 \mu \mathrm{M}$ was considered the approximate median lethal concentration both for flubendiamide and copper.

\section{Viability of splenocytes}

Fluorescent microscopic examination of flubendiamide $(40 \mu \mathrm{M})$ and copper $(40 \mu \mathrm{M})$ alone-treated splenocytes respectively showed 71.88 and $81.11 \%$ nonviable cells compared to $5.41 \%$ in control and $8.59 \%$ in DMSO-treated cells (Table 2). Following concomitant in vitro treatment of splenocytes with xenobiotics and antioxidants- resveratrol, catechin, curcumin and $\alpha$-tocopherol, the percentage of the nonviable splenocytes was found to decrease and effect of all these four antioxidants was concentration-dependent (Table 2). Out of these tested antioxidants, based on their comparative efficacy on equimolar concentration basis $(10 \mu \mathrm{M})$, resveratrol was found to be the most effective against flubendiamide in reducing the percentage of nonviable splenocytes, and the order of ameliorative potential of these antioxidants was: resveratrol $>$ curcumin $\approx \alpha$-tocopherol $>$ catechin (Table 2 ). Similarly, resveratrol was also found to be the most effective against copper-induced viability losses in splenocytes; and the order of ameliorative potential against copper was: resveratrol $>\alpha$-tocopherol $>$ curcumin $>$ catechin.

\section{Tunel assay}

Splenocytes exposed to $40 \mu \mathrm{M}$ flubendiamide or copper showed higher number of Tunel-positive (Tunel+ve) cells compared to those in negative or vehicle control (DMSO) groups as shown in Figs. 1 and 2, respectively. Compared to flubendiamide, copper was more potent in 


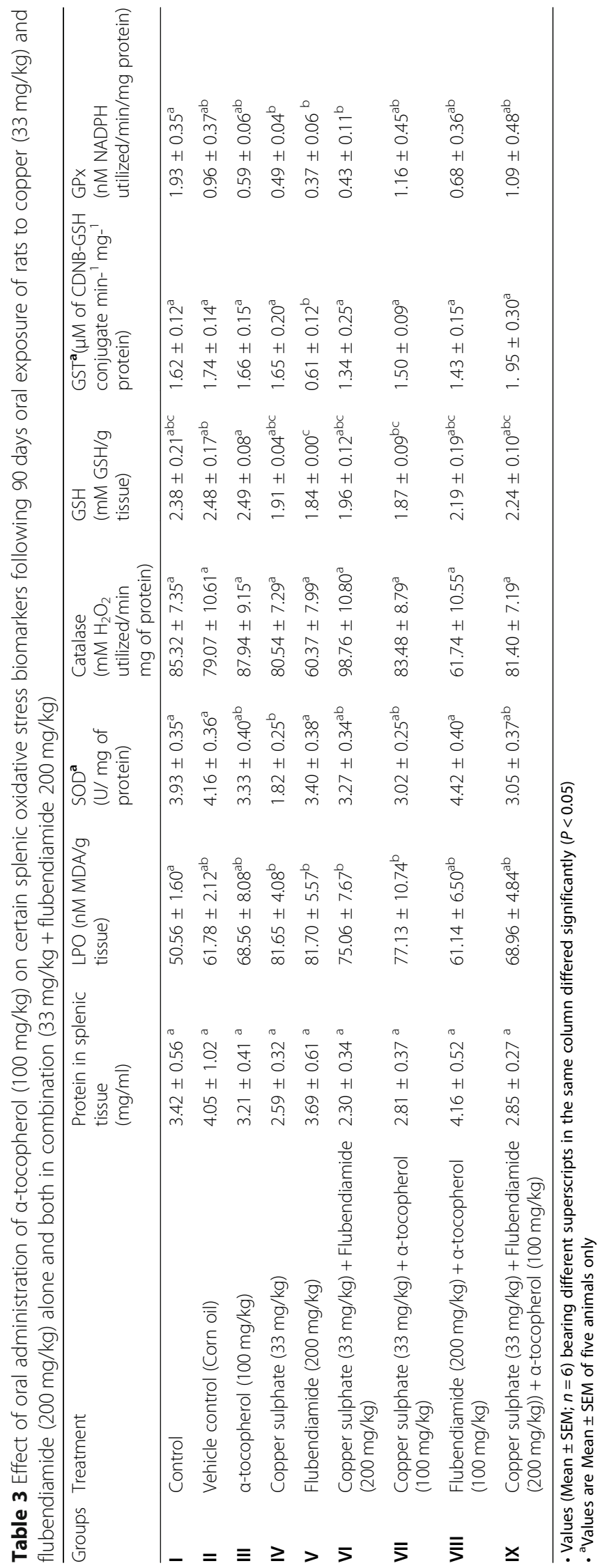




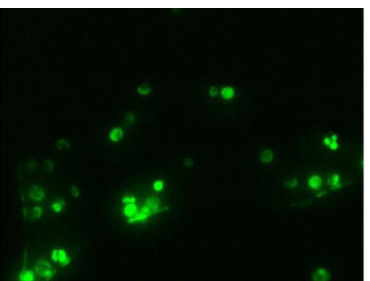

Positive control (human lymphoma cell)

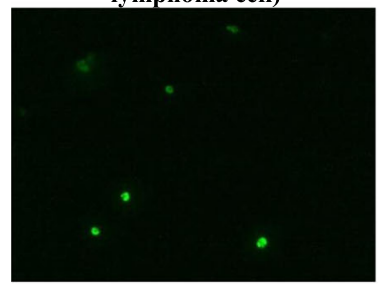

Flubendiamide $(40 \mu \mathrm{M})+$ Resveratrol $(5 \mu \mathrm{M})$

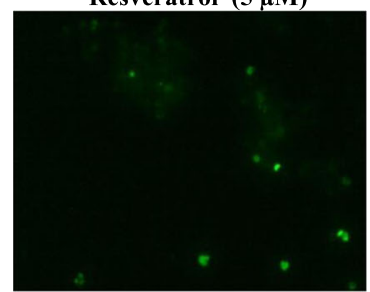

Flubendiamide $(40 \mu \mathrm{M})+$ Catechin $(20 \mu \mathrm{M})$

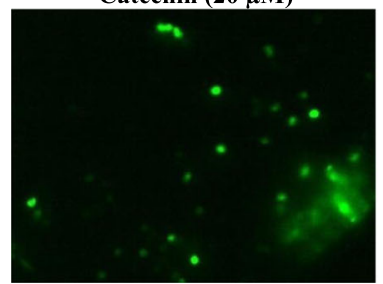

Flubendiamide $(40 \mu \mathrm{M})+\alpha-$ tocopherol $(5 \mu \mathrm{M})$

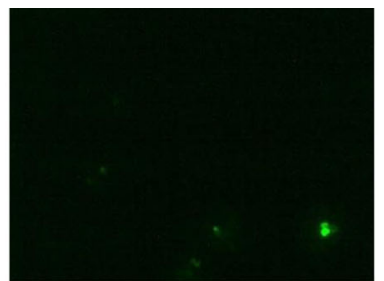

DMSO

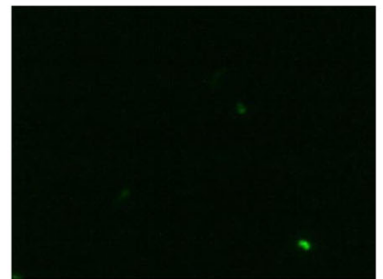

Flubendiamide $(40 \mu \mathrm{M})+$ Resveratrol $(10 \mu \mathrm{M})$

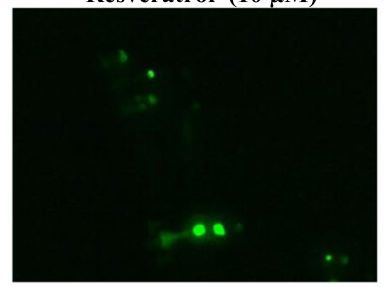

Flubendiamide $(40 \mu \mathrm{M})+$ Curcumin $(5 \mu \mathrm{M})$

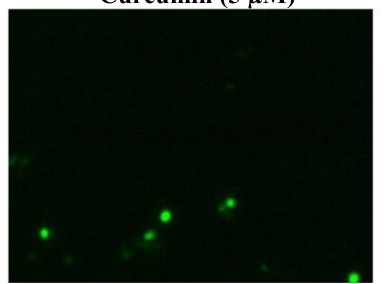

Flubendiamide $(40 \mu \mathrm{M})+$ a-tocopherol $(10 \mu \mathrm{M})$

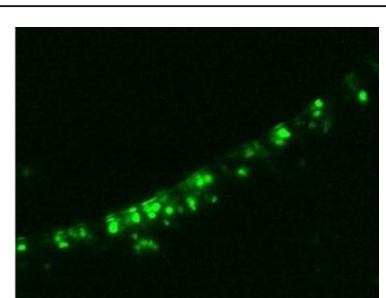

Flubendiamide (40 $\mu \mathrm{M})$

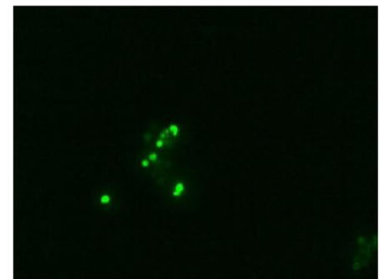

Flubendiamide $(40 \mu \mathrm{M})+$ Catechin $(10 \mu \mathrm{M})$

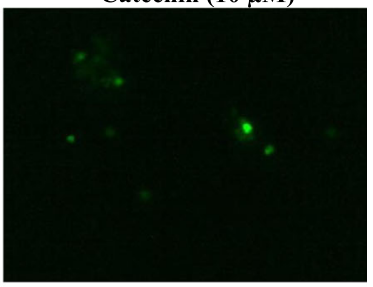

Flubendiamide $(40 \mu \mathrm{M})+$ Curcumin $(10 \mu \mathrm{M})$

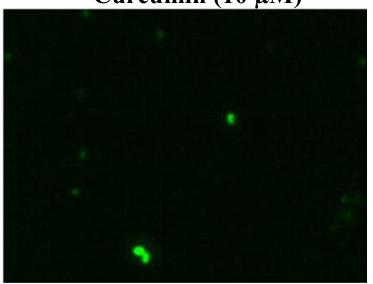

Flubendiamide $(40 \mu \mathrm{M})+$ $\alpha$-tocopherol $(20 \mu \mathrm{M})$

Fig. 1 Representative photographs of rat splenocytes showing TUNEL + ve cells (40 X) following in vitro exposure to median lethal concentration of flubendiamide alone $(40 \mu \mathrm{M})$ and in the presence of different concentrations of natural antioxidants-resveratrol, catechin, curcumin and a-tocopherol

producing Tunel+ve splenocytes, and compared to the flubendiamide or copper-alone treated splenocytes, marked reduction in Tunel+ve cells was observed in the splenocytes treated concurrently with either of the xenobiotic (flubendiamide or copper) and different antioxidants (resveratrol 5 and $10 \mu \mathrm{M}$, catechin 10 and $20 \mu \mathrm{M}$, curcumin 5 and $10 \mu \mathrm{M}$ or $\alpha$-tocopherol 5,10 and $20 \mu \mathrm{M}$ ) as shown in Figs. 1 and 2. However, based on the efficacy of different antioxidants at equimolar concentration basis i.e. $10 \mu \mathrm{M}$, resveratrol was most effective in reducing the number of Tunel+ve cells induced by flubendiamide (Fig. 1) and the overall order of efficacy of different antioxidants was resveratrol $>$ curcumin $>\alpha$-tocopherol $>$ catechin. Just like their efficacy against flubendiamide, all these were effective in reducing copper-induced increase in number of Tunel+ve cells and the overall order of efficacy of different antioxidants was curcumin $>$ catechin $\geq \alpha$-tocopherol $\geq$ resveratrol (Fig. 2). However, contrary to resveratrol, curcumin was most effective against copper.

\section{Micronuclei formation}

Flubendiamide and copper alone treated splenocytes showed micronuclei formation in 7.86 and $9.16 \%$ cells respectively compared to $0.96 \%$ in negative control and $1.36 \%$ in DMSO-treated splenocytes (Table 2; Fig. 3). Dexamethasone-induced micronuclei formation $(7.6 \%)$ was much higher compared to that in negative control and DMSO-treated splenocytes. Almost a similar percentage of micronuclei were observed in splenocytes treated with flubendiamide $(7.86 \%)$ or copper $(9.16 \%)$ as summarized in Table 2. Ameliorative efficacy studies with resveratrol, catechin, curcumin and $\alpha$-tocopherol against flubendiamide 


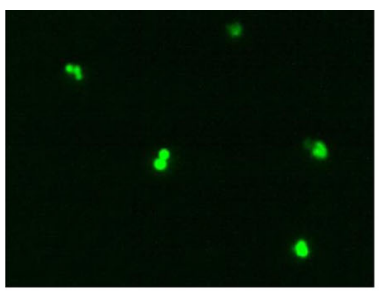

Positive control (human lymphoma cells)

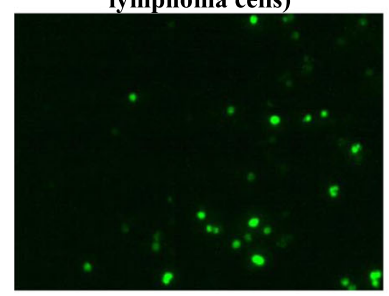

Copper $(40 \mu \mathrm{M})+$ Resveratrol $(5 \mu \mathrm{M})$

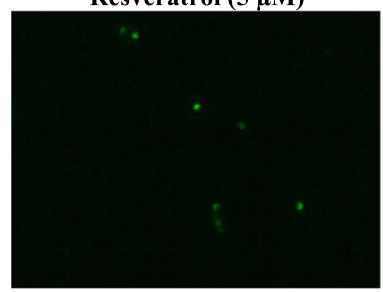

Copper $(40 \mu \mathrm{M})+$ Catechin $(20 \mu \mathrm{M})$

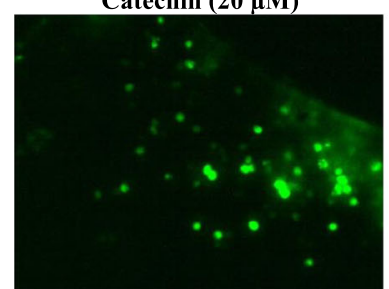

Copper $(40 \mu \mathrm{M})+$ $\alpha$-tocopherol (5 $\mu \mathrm{M})$

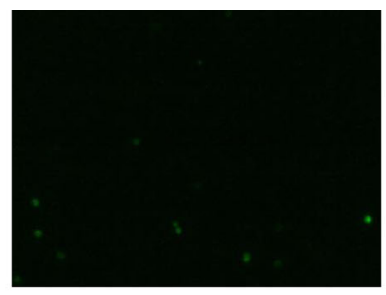

DMSO

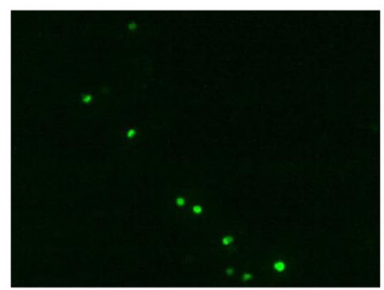

Copper (40 $\mu \mathrm{M})+$ Resveratrol $(10 \mu \mathrm{M})$

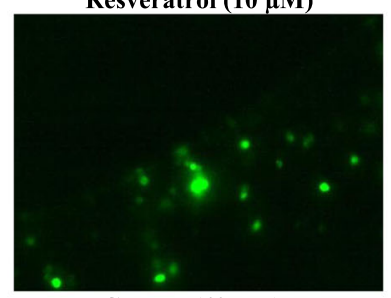

Copper $(40 \mu \mathrm{M})+$

Curcumin $(5 \mu \mathrm{M})$

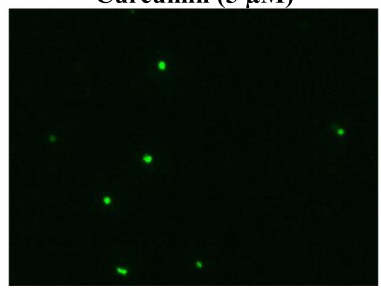

Copper $(40 \mu \mathrm{M})+$ $\alpha$-tocopherol $(10 \mu \mathrm{M})$

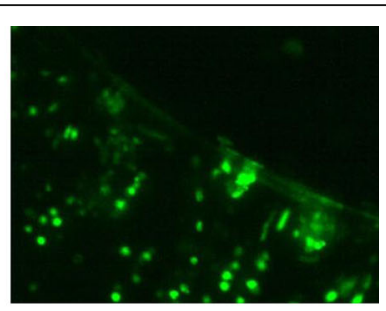

Copper $(40 \mu \mathrm{M})$

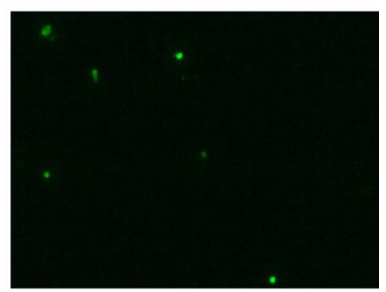

Copper $(40 \mu \mathrm{M})+$

Catechin $(10 \mu \mathrm{M})$

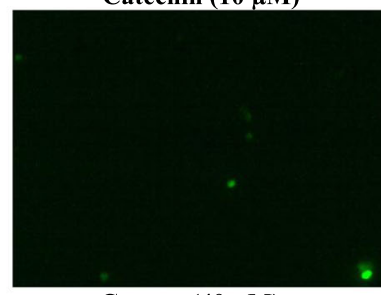

Copper $(40 \mu \mathrm{M})+$

Curcumin $(10 \mu \mathrm{M})$

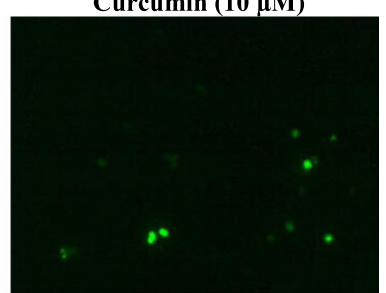

Copper $(40 \mu M)+$

$\alpha$-tocopherol $(20 \mu \mathrm{M})$

Fig. 2 Representative photographs of rat splenocytes showing TUNEL + ve cells $(40 \mathrm{X})$ following in vitro exposure to median lethal concentration of copper alone $(40 \mu \mathrm{M})$ and in the presence of different concentrations of natural antioxidants-resveratrol, catechin, curcumin and a-tocopherol

or copper-induced micronuclei formation revealed marked reduction in micronuclei formation by all four test antioxidants. The order of ameliorative efficacy of these antioxidants on equimolar basis $(10 \mu \mathrm{M})$ against flubendiamide was resveratrol $>$ curcumin $\approx$ catechin $>\alpha$-tocopherol while resveratrol $\approx \alpha$-tocopherol $>$ curcumin $>$ catechin against copper-induced micronuclei formation (Table 2).

\section{DNA fragmentation}

DNA of the flubendiamide, copper and dexamethasone treated splenocytes showed more shearing compared to the DNA of untreated splenocytes. DNA of the splenocytes treated concurrently with flubendiamide and equimolar concentration $(10 \mu \mathrm{M})$ of resveratrol, catechin or $\alpha$-tocopherol also showed almost similar pattern of DNA shearing as observed in the DNA of flubendiamide alone treated splenocytes (Fig. 4). But DNA samples from curcumin $(10 \mu \mathrm{M})+$ flubendiamide treated splenocytes showed less shearing compared to those treated with resveratrol + flubendiamide, catechin + flubendiamide or $\alpha$-tocopherol + flubendiamide. Just like flubendiamide and curcumin treated splenocytes, DNA samples from copper + curcumin treated splenocytes also showed comparatively less shearing than in the DNA from splenocytes treated with copper and other antioxidants (resveratrol, catechin, $\alpha$-tocopherol) as shown in Fig. 5.

\section{Comet formation}

Comet formation data in splenocytes following their exposure to flubendiamide $(40 \mu \mathrm{M})$, copper $(40 \mu \mathrm{M})$ and dexamethasone $(20 \mu \mathrm{M})$ alone revealed 22.90, 29.59 and $27.69 \%$ comets formation compared to 


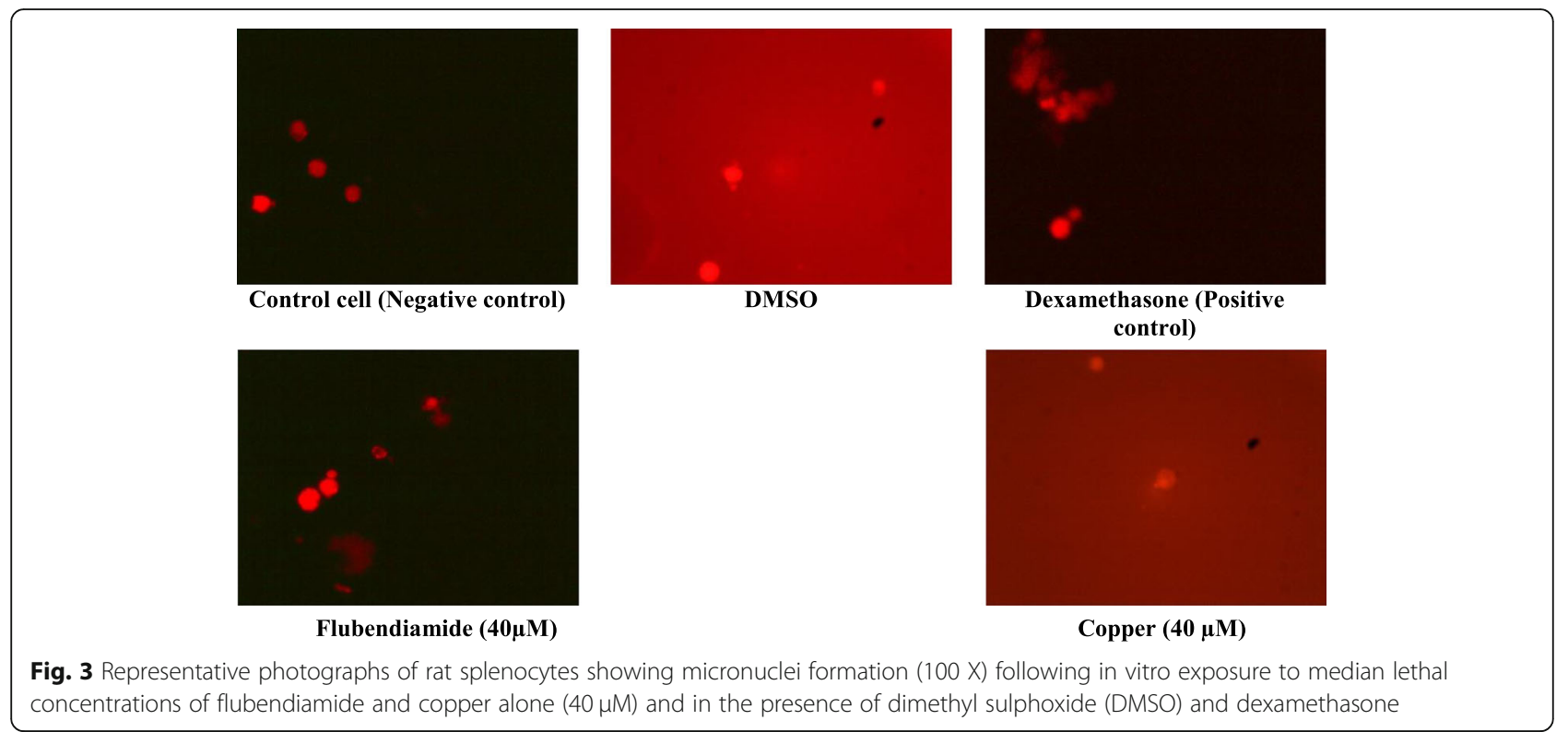

$3.09 \%$ in negative control and $4.58 \%$ in DMSO-treated splenocytes (Table 2; Fig. 6). Resveratrol, catechin, curcumin and $\alpha$-tocopherol $(10 \mu \mathrm{M}$ each) were found to reduce the percentage of comets formed in flubendiamide and copper-treated splenocytes and the effect of all these agents was concentration-dependent (Table 2). Further, the ameliorative efficacy potential of these antioxidants on equimolar basis against

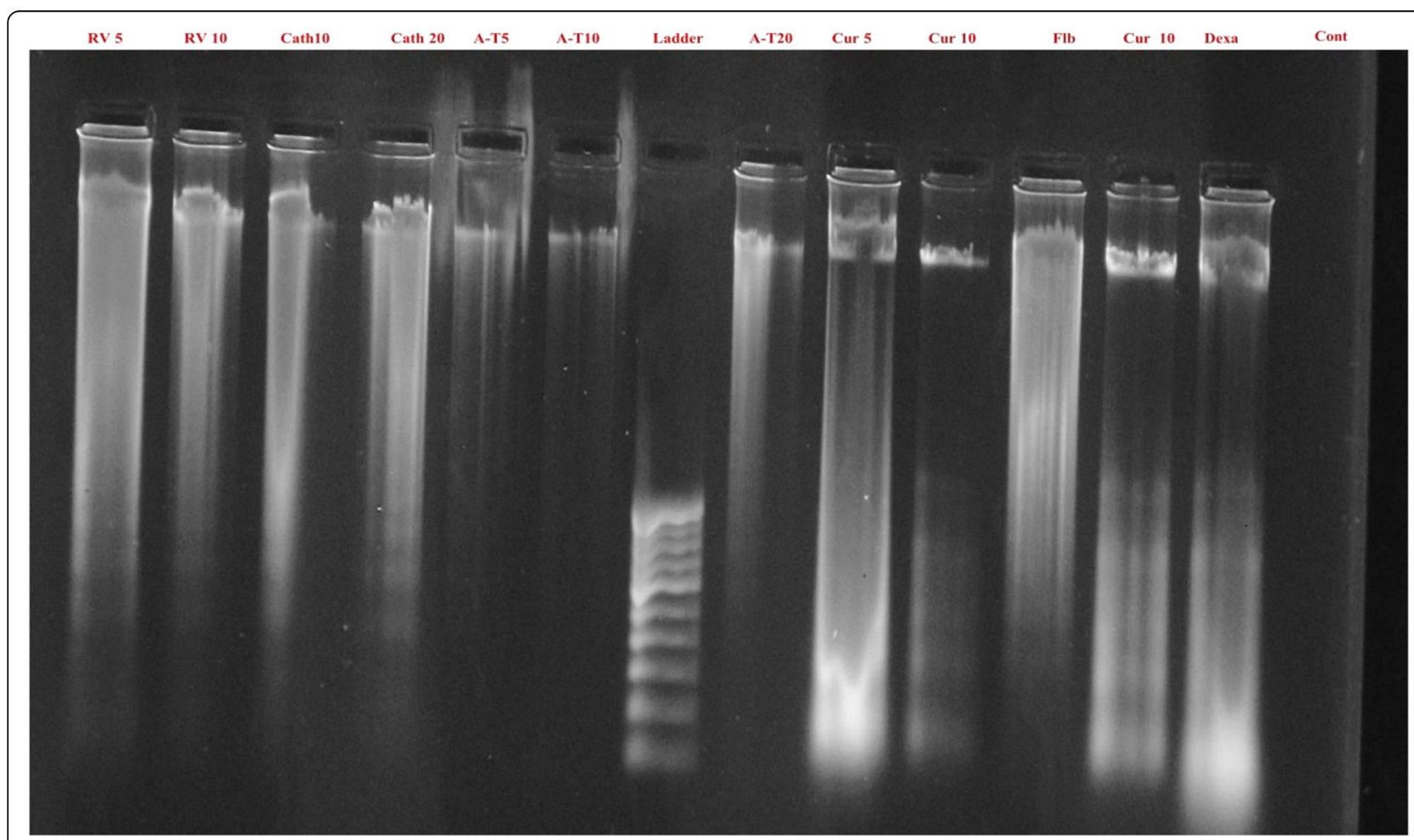

Fig. 4 In vitro effect of median lethal concentration of flubendiamide and natural antioxidants at different concentrations on DNA fragmentation pattern in rat splenocytes. RV: Resveratrol (5 and $10 \mu \mathrm{M})$, Cath: Catechin (10 and $20 \mu \mathrm{M}), \mathrm{A}-\mathrm{T}$ : a-tocopherol (5, 10 and $20 \mu \mathrm{M})$, Cur: Curcumin (5 and $10 \mu \mathrm{M})$, Flb: Flubendiamide, Dexa: Dexamethasone,Cont: Control 

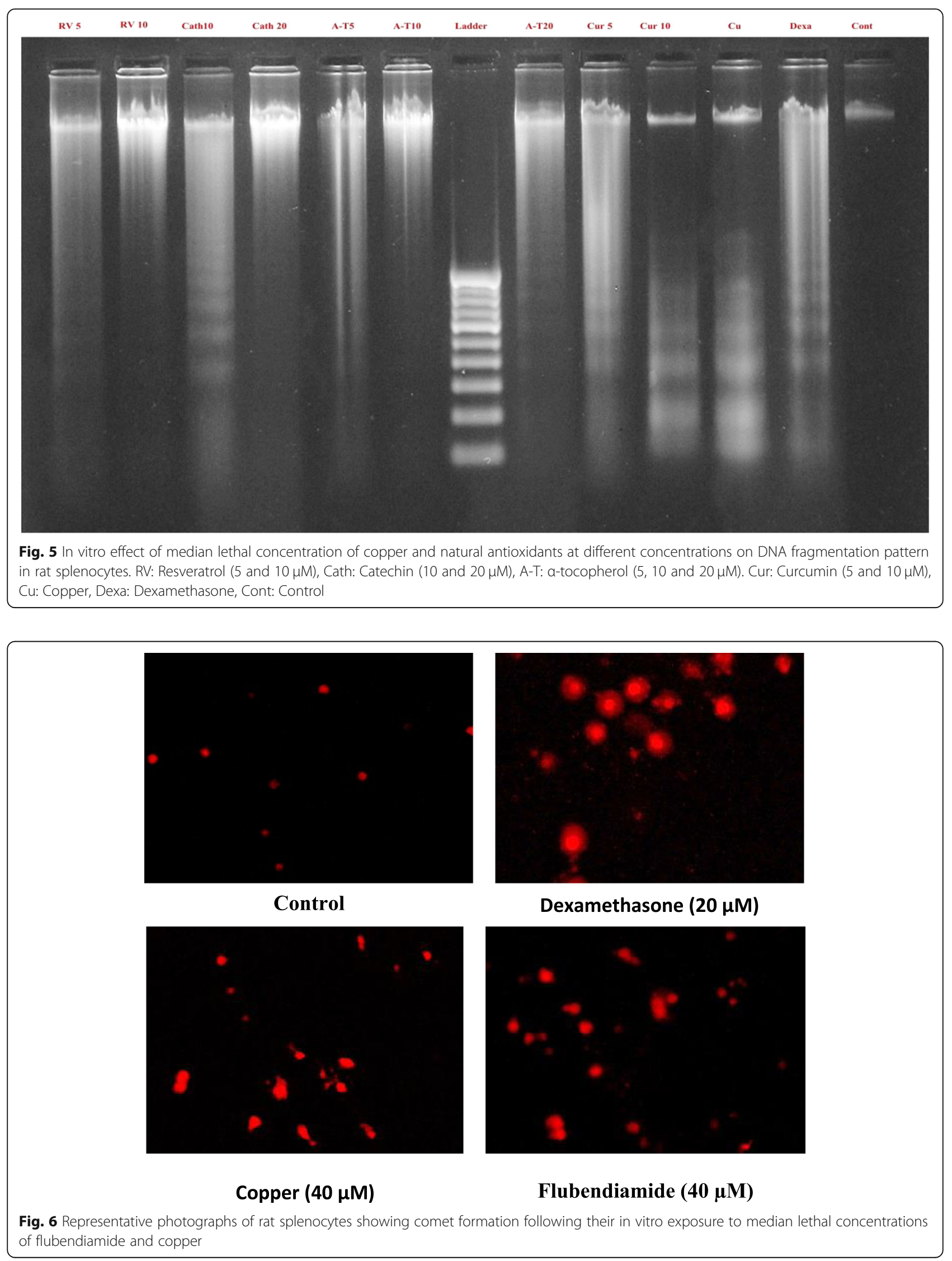
flubendiamide was $\alpha$-tocopherol $\approx$ curcumin $>$ catechin > resveratrol while resveratrol $>$ curcumin $>$ catechin $>\alpha$-tocopherol against copper (Table 2).

\section{Phase II-in vivo chronic toxicity study}

Oxidative stress biomarkers data of rat spleens after 90 days of daily oral exposure to copper and flubendiamide alone and both these in combination (copper + flubendiamide) and those treated simultaneously with $\alpha$ tocopherol and test xenobiotics are presented in Table 3. Lipid peroxidation levels in rats of the groups exposed to flubendiamide or copper alone and copper + flubendiamide were significantly $(P<0.05)$ higher, while reduced glutathione (GSH) levels in flubendiamide and copper alone and copper + flubendiamide treated groups were moderately decreased when compared with the control group. Similarly, glutathione peroxidase (GPx) activity was found to be significantly $(P<0.05)$ decreased in rat groups exposed to copper, flubendiamide and copper + flubendiamide compared to group I rats. Glutathione-S-transferase (GST) activity in flubendiamide alone group was significantly $(P<0.05)$ lower $\left(0.61 \pm 0.12 \mu \mathrm{M}\right.$ of CDNB-GSH conjugate min- ${ }^{1} \mathrm{mg}_{-}{ }^{1}$ protein) than in rest of the groups (Table 3). Further significant $(P<0.05)$ decrease in SOD activity was also observed in copper alone exposed group. Total protein content and catalase activity did not differ significantly between the control and any of the xenobiotics-treated groups. On simultaneous exposure of rats to xenobiotics and $\alpha$-tocopherol, decrease in lipid peroxidation level and improvement in antioxidants (SOD, GST, GPx, catalase and GSH) cellular defense in splenic tissue of rats were observed compared to the rats exposed to xenobiotics alone.

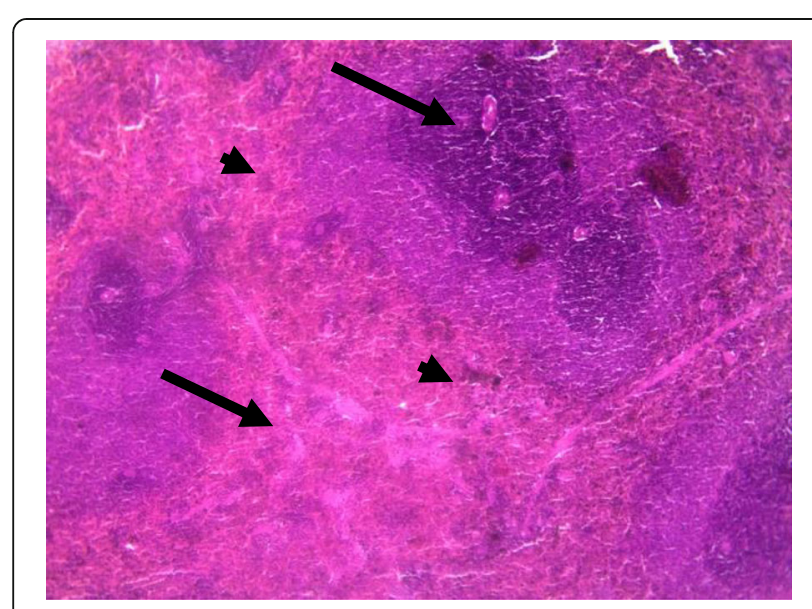

Fig. 7 Section of spleen of rat from control group showing healthy histoarchitecture with red (arrow head) and white pulp (arrow) in splenic parenchyma (10X H\&E stain)

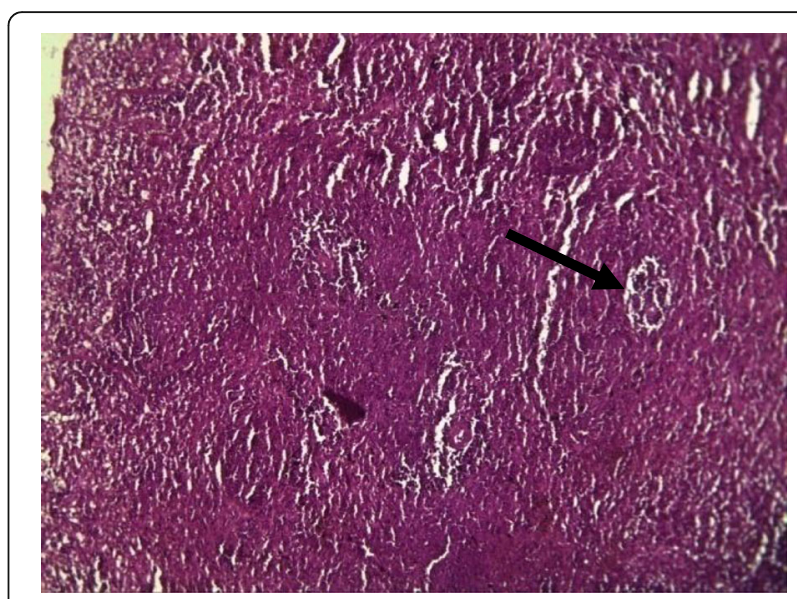

Fig. 8 Spleen section of copper sulphate $(33 \mathrm{mg} / \mathrm{kg}$ ) exposed group (IV) showing mild depletion of lymphoid tissue from white pulp (arrow) (10 X H\&E stain)

Rat spleens from the control groups (I, II and III) exhibited normal histoarchitecture characterized by normal red and white pulps (Fig. 7). Spleen sections of copper sulphate group (IV) rats showed mild depletion of the lymphoid tissue from the white pulp (Fig. 8). Flubendiamide alone $(\mathrm{V})$ group spleen showed separation of splenocytes and rearification in splenic parenchyma (Fig. 9). But spleen sections of copper + flubendiamide treatment group (VI) exhibited separation of splenocytes and rearification in splenic parenchyma (Fig. 10). Concurrent treatment of the rats of groups VII, VIII and IX with $\alpha$-tocopherol and copper sulphate, $\alpha$-tocopherol and flubendiamide, and $\alpha$-tocopherol and combination of flubendiamide and copper, respectively, showed almost normal histoarchitecture of spleens as shown in Figs. 11, 12 and 13, respectively.

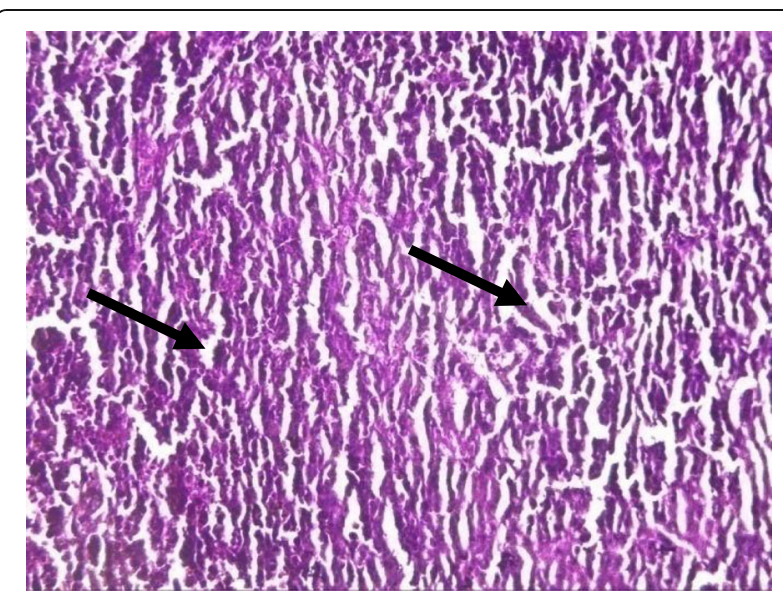

Fig. 9 Spleen section of flubendiamide $(200 \mathrm{mg} / \mathrm{kg})$ exposed group (V) showing separation of splenocytes and rarefication (arrow) in splenic parenchyma (10 X H\&E stain) 


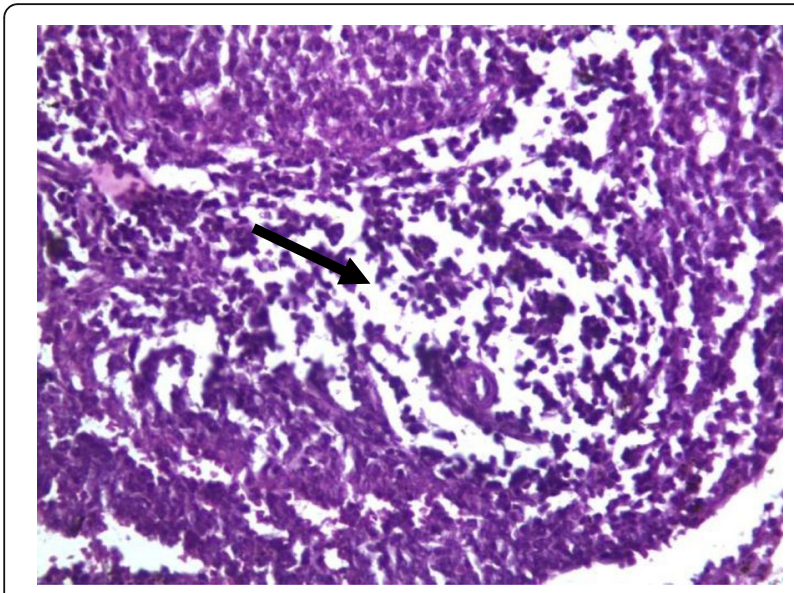

Fig. 10 Spleen section of flubendiamide $(200 \mathrm{mg} / \mathrm{kg})+$ copper sulphate (33 mg/kg)-exposed group (VI) showing separation of splenocytes and rarefication (arrow) in splenic parenchyma (40 X H\&E stain)

\section{Discussion}

Humans and animals are being continuously exposed to mixture of agrochemicals and metals due to agricultural practices, working in heavy metals infested environment and use of ectoparasiticides and other chemicals in household practices [50, 51]. Therefore, an interaction study between different xenobiotics in human and animal systems due to concurrent exposure to these chemical moieties along with their remedial measures seems very important.

No information is available on the cyto-genotoxic effects of flubendiamide and its possible mechanism. Markedly higher percentage of nonviable splenocytes in flubendiamide and copper treated groups evidently suggests cytotoxic effects of flubendiamide and copper in

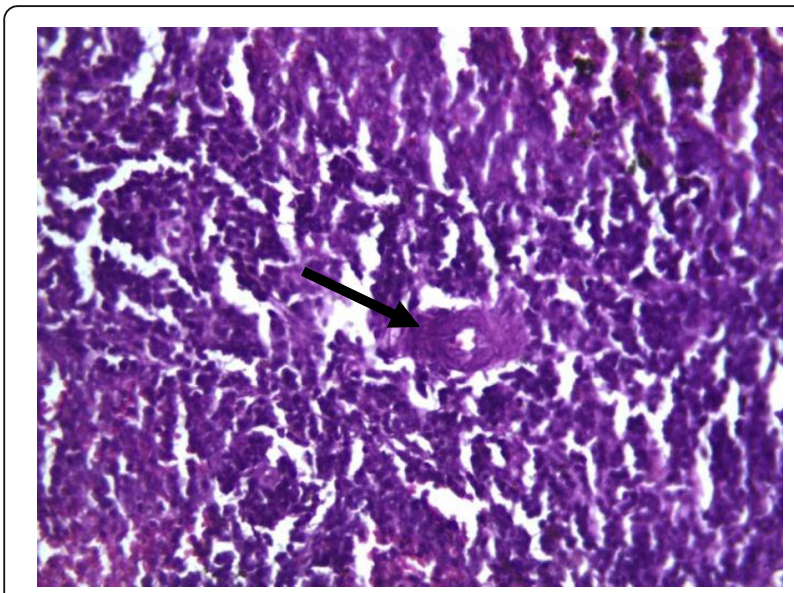

Fig. 11 Spleen section of rats treated with a-tocopherol (100 mg/ $\mathrm{kg})+$ copper sulphate $(33 \mathrm{mg} / \mathrm{kg}$ ) of group (VII) showing normal histo-architecture with abundant lymphoid tissue in the white pulp (arrow) suggestive of amelioration (40 X H\&E stain)

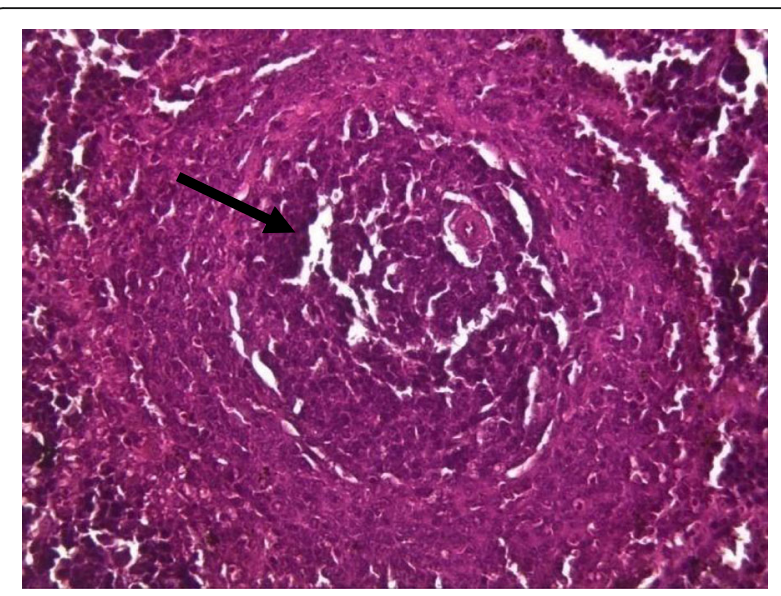

Fig. 12 Spleen section of rats treated with a-tocopherol (100 mg/ $\mathrm{kg})+$ flubendiamide $(200 \mathrm{mg} / \mathrm{kg}$ ) of group (VIII) showing normal histoarchitecture, abundant lymphoid tissue in the white pulp (arrow) suggestive of amelioration (40 X H\&E stain)

rat splenocytes similar to those reported with certain neonicotinoid insecticides in human peripheral blood lymphocytes [52]. Increase in the number of Tunel+ve cells in the present study are in agreement with increase in number of Tunel+ve germ cells in seminiferous tubules of imidacloprid-treated rats [53] and Tunel+ve fragmented DNA in brain and hippocampus of coppertreated mice and rats $[54,55]$. Our findings suggest the ability of flubendiamide and copper to interact with double-stranded DNA (dsDNA) and induce cellular damage which enables TdT to bind with $3^{\prime} \mathrm{OH}$ label blunt ends of dsDNA and serve as a marker of apoptosis.

Micronuclei assay is one of the most sensitive DNA damage indicator tests and is widely used for evaluation

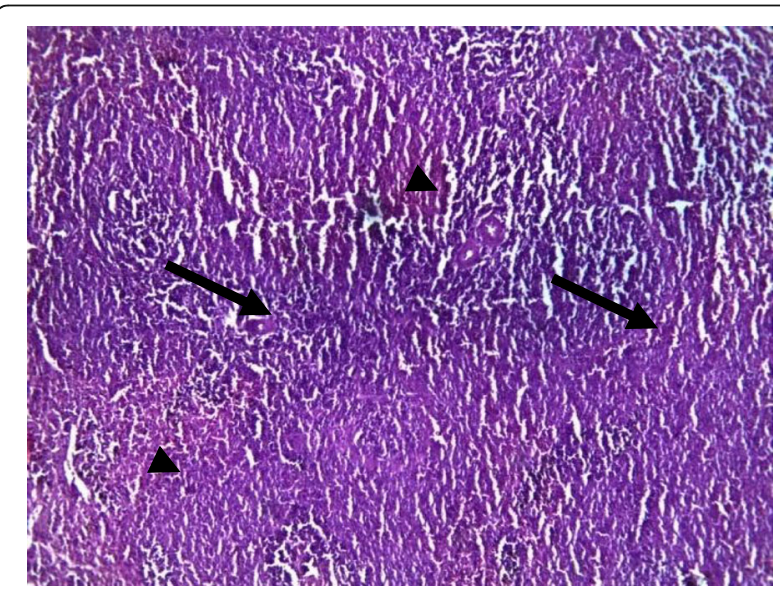

Fig. 13 Spleen of rats treated with a-tocopherol $(100 \mathrm{mg} / \mathrm{kg})+$ flubendiamide $(200 \mathrm{mg} / \mathrm{kg})+$ copper sulphate $(33 \mathrm{mg} / \mathrm{kg})$ of group (IX) showing apparently healthy histoarchitecture with ample red (arrow head) and white pulp (arrow) in splenic parenchyma suggestive of amelioration (10 X H\&E stain) 
of genotoxic potential of environmental contaminants [56]. Micronuclei assay is employed to detect clastogen and aneugen properties of xenobiotics and determine mitotic delay, apoptosis, chromosome breakage, chromosome loss and non-disjunction potential of xenobiotics $[57,58]$. Increase in frequency of micronuclei formation in flubendiamide-treated splenocytes was almost comparable to that induced by dexamethasone. Similar micronuclei forming effect of chlorpyrifos in fish erythrocytes [59] and imidacloprid in human peripheral blood lymphocytes has been reported [60]. Copper-induced increase in frequency of micronuclei formation in rat splenocytes is also in agreement with the observations in bone marrow cells of mice following exposure to copper, and erythrocytes [61, 62], gill and liver cells of fish following exposure to cadmium and copper [63]. Other genotoxicity studies have also suggested that copper is a clastogenic agent $[62,64]$.

Apart from increase in number of Tunel+ cells and micronuclei formation, DNA fragmentation and comet assay studies also revealed that interaction of flubendiamide or copper with splenocyte cells resulted in DNA damage which is manifested in the form of DNA strand breaks, laddering appearance of DNA in electrophoretic field and comet formation in alkaline conditions. Comet may be formed due to DNA single strand breaks, DNA double strand breaks, DNA adduct formations, DNADNA and DNA-proteincross-links or due to interaction of these xenobiotics with DNA $[65,66]$. Similar DNA fragmentation in human peripheral blood mononuclear cells [67] and DNA fragmentation along with decrease in cell viability in HepG2 cells following exposure to copper has also been documented [68].

Superoxide dismutase, catalase and glutathione peroxidase are the main defense against free radicals-induced oxidative stress and these act in concert with reduced glutathione and other antioxidants such as $\alpha$-tocopherol and selenium that protect against the adverse effects of ROS [69]. Increased lipid peroxidation, a decrease in activities of antioxidant enzymes (SOD, GST, GPx) and GSH, separation of splenocytes, and rearification of splenic parenchyma revealed cellular damaging effects of flubendiamide and copper due to generation of oxidative stress. Depletion of GSH occurs as a result of excessive GSH consumption during oxidative stress [70, 71]. Further, GSH is not only a substrate for GPx, but is also involved in electrophile detoxification, free radical scavenging, $\alpha$-tocopherol generation, phase II conjugation and other reactions [72, 73]. Glutathione-S-transferase catalyzes conjugation of glutathione with a number of electrophilic xenobiotics and prevents their interaction with cellular proteins and nucleic acids, and plays an important role in cellular defense against these xenobiotics [74, 75]. Therefore, inadequate detoxification of flubendiamide or copper or both these in combination, which amplified ROS generation and resulted in oxidative damage, may be responsible for these test compoundsinduced decrease in membrane potential and increase in permeability to $\mathrm{H}^{+}$and other ions, and eventually the cell contents release [76].

Copper-induced cyto-genotoxicity in the present study seems to be due to propensity of free $\mathrm{Cu}$ ions to participate in formation of ROS by redox cycling and copperinduced formation of hydroxyl radicals from hydrogen peroxide via Haber-Weiss reaction [77-79]. Lipid peroxy radicals damage cells by changing the fluidity and permeability of cell membrane or by attacking the cellular DNA molecule, leading to DNA strand brakes, oxidation of its bases and other intracellular molecules such as proteins [80, 81]. Copper-induced oxidative stress and apoptosis in kidney via intrinsic and extrinsic apoptotic pathways is also well documented [82].

Simultaneous treatment of splenocytes with flubendiamide or copper and either of these along with resveratrol, curcumin, catechin or $\alpha$-tocopherol resulted in marked decrease in percentage of non-viable splenocytes, Tunel+ve cells, and micronuclei and comet formation in splenocytes. Thus evidently suggests the ameliorative potential of these natural antioxidants against flubendiamide and copper-induced cytogenotoxic effects. The protective effect of resveratrol against xenobiotics is linked to decrease in intracellular ROS accumulation, reactive oxygen intermediate (ROI) generation and lipid peroxidation [83, 84]. Attenuation of pyrogallol-induced hepatic toxicity and oxidative stress changes in hepatic damage and alterations in xenobiotic metabolizing enzymes by resveratrol has also been reported in Swiss mice [85].

Antiapoptotic property of catechin against copper is linked to chelation of $\mathrm{Cu}^{2+}$ and formation of an inactive complex with this metal, and thus prevention of generation of potentially damaging free radicals [86, 87]. Similar antiapoptotic, antioxidant and neuroprotective action of green tea extract, rich in various polyphenols, including catechin, against deltamethrin-induced neurotoxicity by improving oxidative status and DNA fragmentation, and suppressing the expression of apoptotic TP53 and COX2 genes has been reported in male rats [88]. Possibility of involvement of similar protective mechanisms of action of the test antioxidants against copper and flubendiamide-induced cytotoxic effects cannot be ruled out.

Curcumin has been reported to ameliorate the arsenic and fluoride-induced genotoxicity in human peripheral blood lymphocytes [33]. Even curcumin has been demonstrated to be effective against radiations-induced hazards [89]. Protective effect of curcumin against different 
xenobiotics has been attributed to its ability to decrease ROS generation, apoptosis, DNA fragmentation, and cell cycle arrest [33]. Anti-cytogenotoxic effect of curcumin in the present study against flubendiamide and copper could be attributed to its unique conjugated structure which facilitates the coupling reaction at 3 ' position of the curcumin with lipids or due to its typical radical trapping ability as a chain-breaking antioxidant that inhibits lipid peroxidation and reduces oxidative stress [90-93].

$\alpha$-tocopherol is lipophilic in nature which facilitates its entry through cell membrane and thereby quenches free radical species, terminates lipid peroxidation chain reaction and thus interferes with initiation and progression of xenobiotics-induced oxidative damage [94, 95]. $\alpha$ tocopherol produced protective effect against flubendiamide and copper-induced oxidative stress in splenic tissues by modulating the oxidant-antioxidant mechanisms as substantiated by the altered values of different oxidative stress biomarkers. It also normalized the spleen histoarchitecture towards almost normal as observed in rats of control groups. This evident ameliorative potential of $\alpha$-tocopherol is in agreement with our previous findings that studied flubendiamide and copper induced testicular injury [96]. Similar preventive effects of $\alpha$ tocopherol against copper and cadmium-induced cytotoxicity in COS-7 cells [81] and carbofuran-induced genotoxicity in human lymphocytes has also been reported [97].

\section{Conclusions}

Summing up the findings of our in vitro and in vivo studies, it is apparent that flubendiamide and copperinduced alterations in oxidative stress biomarkers interact with cellular subcomponents, especially DNA and result in cytotoxic-insult to splenocytes and spleenhistoarchitecture. Resveratrol is most effective against flubendiamide and curcumin against copper-induced cytotoxic effects, therefore, both these natural phyotconstituent antioxidants hold promising potential for their use in fortifying the conventional food-ingredients to prevent the adverse effects of xenobiotics on human and animals health. However, further studies on signaling intermediary steps and alterations in gene-expression are also warranted.

\footnotetext{
Abbreviations

LPO: Lipid peroxidation; GSH: Reduced glutathione; CAT: Catalase; GPx: Glutathione peroxidase; GST: Glutathione-S-transferase; SOD: Superoxide dismutase; ROS: Reactive oxygen species; IAEC: Institutional Animals Ethics Committee; PBS: Phosphate buffer saline; RPMI: Roswell Park Memorial Institute; HBSS: Hank's balanced salt solution; SDS: Sodium dodecyl sulfate; NMA: Normal melting agarose; LMPA: Low melting point agarose; DMSO: Dimethyl sulfoxide
}

\section{Acknowledgements}

The authors are thankful to the Dean, College of Veterinary Science and Animal Husbandry, and Head of the Pharmacology Department for providing the necessary facilities in the laboratories established under Niche Area of Excellence Programme of ICAR and Rashtriya Krishi Vikas Yojana of Govt. of India. Routine financial assistance provided by the University for Doctoral Research to the first author is also duly acknowledged.

\section{Authors' contributions}

RM searching of literature, conceiving of research plan and execution of research work. AP planning of the experimental design for in vitro study. AR supervision of the oxidative stress biomarkers study and assistance in laboratory work. SPS DNA isolation from splenocytes and gel-electrophoresis; and statistical analysis of data. DS DNA fragmentation assay and interpretation of results of DNA fragmentation assay. RK assistance and guidance in histopathological studies including interpretation. SKG planning and supervision of research as Guide, interpretation of data and manuscript preparation. All the authors have read and approved the final manuscript.

\section{Funding}

Part of the PhD thesis of the first author. No additional funding was obtained for this study.

\section{Availability of data and materials}

Data-sets generated and/or analyzed during the current study are available in the thesis submitted by the first author in the University library and also available with the corresponding author on reasonable request.

\section{Ethics approval and consent to participate}

Present study was conducted on healthy male Wistar rats and the experimental protocol was dully approved by Institutional Animal Ethics Committee (IAEC) vide communication No. 79 IAEC/13 dated 16.07 .13 (U.P. Pandit Deen Dayal Upadhyaya Pashu Chikitsa Vigyan Vishwavidyalaya Evam Go-Anusandhan Sansthan (DUVASU), Mathura-281001, India.

\section{Consent for publication}

Not applicable.

\section{Competing interests}

The authors declare that they have no competing interests.

\section{Author details}

${ }^{1}$ Department of Veterinary Pharmacology and Toxicology, College of Veterinary and Animal Sciences, Sardar Vallabhbhai Patel University of Agriculture and Tecahnology, 250110, Meerut, India. ${ }^{2}$ Department of Veterinary Pharmacology and Toxicology, College of Veterinary Science and Animal Husbandry, U.P. Pt. Deen Dayal Upadhyay Pashu Chikitsa Vigyan Vishwavidyalaya Evam Go- Anusandhan Sansthan (DUVASU), -281001, Mathura, India. ${ }^{3}$ Division of Goat Health, Central Institute for Research on Goat (CIRG), Makhdoom, Farah, Mathura, Uttar Pradesh 281122, India. ${ }^{4}$ Department of Animal Genetics \& Breeding, College of Veterinary Science and Animal Husbandry, U.P. Pt. Deen Dayal Upadhyay Pashu Chikitsa Vigyan Vishwavidyalaya Evam Go-Anusandhan Sansthan (DUVASU), 281001, Mathura, India. ${ }^{5}$ Department of Veterinary Pathology, College of Veterinary Science and Animal Husbandry, U.P. Pt. Deen Dayal Upadhyay Pashu Chikitsa Vigyan Vishwavidyalaya Evam Go-Anusandhan Sansthan (DUVASU), 281001, Mathura, India.

Received: 29 September 2018 Accepted: 20 March 2020 Published online: 23 April 2020

\section{References}

1. Ebbinghaus-Kintscher U, Luemmen P, Lobitz N, et al. Phthalic acid diamides activate ryanodine sensitive $\mathrm{Ca}^{2} \mathrm{C}$ release channels in insect. Cell Calcium. 2006:39:21-33.

2. Masaki T, Yasokawa N, Tohnishi M. Phthalic acid diamides activate ryanodine sensitive $\mathrm{Ca}^{2}$ - release channels in insects. Cell Calcium. 2006;39: 21-33.

3. JMPR (Joint Meeting on Pesticide Residues). Report of the joint meeting of the FAO panel of experts on pesticide residues in food and the 
environment and the $\mathrm{WHO}$ core assessment group on pesticide residues at the request of codex committee on pesticide residues Italy; 2010. p. 345-82.

4. Miyahana K. Micronucleus test of NNI-0001 in mice. Unpublished report No. LSRC-T02-089A from Nihon Nohyaku Co., Ltd, Osaka, Japan. Submitted to WHO by Bayer CropScience AG, Monheim, Germany. (2003).

5. Herbold B. NNI-0001, micronucleus-test on the male mouse. Unpublished report No. AT01775 from Bayer Health Care, Wuppertal, Germany. Submitted to WHO by Bayer Cropscience AG, Monheim, Germany. (2005).

6. Tohnishi M, Nakao H, Furuya T, et al. Flubendiamide, a novel insecticide highly active against lepidopterous insect pests. J Pestic Sci. 2005;30:354-60

7. Kaur K, Kaur R. Occupational Pesticide Exposure, Impaired DNA Repair, and Diseases. Ind J Occup Environ Med. 2018;22(2):74-81.

8. EC. Opinion of the Scientific Committee on Food (SCF) on the upper intake level of copper (27 March 2003). (2003). http://ec.europa.eu/food/fs/sc/scf/ out176_en.pdf.

9. Shen HM, Lin Y, Choksi S, et al. Essential roles of receptor-interacting protein and TRAF2 in oxidative stress-induced cell death. Mol Cell Biol. 2004;24: 5914-22.

10. Gaetke LM, Chow CK. Copper toxicity, oxidative stress, and antioxidant nutrients. Toxicology. 2003;189:147-63.

11. Toplan S, Dariyerli N, Ozcelik D, Akyolcu MC. The effects of copper application on oxidative and antioxidant systems in rats. Trace Elem Elect. 2005;22:178-81.

12. Zhang SS, Noordin MM, Rahman SO, Haron J. Effects of copper overload on hepatic lipid peroxidation and antioxidant defense in rats. Vet Hum Toxicol. 2000;42:261-4

13. Boone C, Gervais JA, Luukinen B, Buhl K, Stone D. Copper Sulfate Technical Fact Sheet; National Pesticide Information Center, Oregon State University Extension Services. 2012. http://npic.orst.edu/factsheets/cuso4tech.pdf. Oregon State University and the U.S. Environmental Protection Agency (cooperative agreement \#X8-83947901).

14. Cano AP, Gillado AV, Montecillo AD, Herrera MU. Copper sulfate-embedded and copper oxide-embedded filter paper and their antimicrobial properties. Mater Chem Phys. 2018;207:147-53

15. Central Water Commission, Ministry of Water Resources, River Development and Ganga Rejuvnation, Government of India (CWC, GOI). Status of trace and toxic metals in Indian rivers. River Data Compilation -2 Directorate Planning and Development Organisation New Delhi 110066. 2018.

16. Filho DW, vila Júnior SÁ, Possamai FP, Possamai FP, Parisotto EB, Moratelli AM, Garlet TR, Ina'cio DB, Torres MA, Colepicolo P, Dal-Pizzol F. Antioxidant therapy attenuates oxidative stress in the blood of subjects exposed to occupational airborne contamination from coal mining extraction and incineration of hospital residues. Ecotoxicology. 2010;19:1193-200.

17. Lobo V, Patil A, Pathak A, Chandra N. Free radicals, antioxidants and functional foods: impact on human health. Pharmacogn Rev. 2010;8:118-26.

18. Halliwell B. How to characterize an antioxidant- an update. Biochem Soc Symp. 1995;61:73-101.

19. Wolf $\mathrm{G}$. The discovery of the antioxidant function of vitamin $\mathrm{E}$ : the contribution of Henry a. Mattill J Nutr. 2005;135:363-6.

20. Yavuz T, Delibas N, Yildirim B, et al. Vascular wall damage in rats induced by methidathion and ameliorating effect of vitamins $\mathrm{E}$ and $\mathrm{C}$. Arch Toxicol. 2004;78:655-9

21. Herrera E, Barbas C. Vitamin E: action, metabolism and perspectives. J Physiol Biochem. 2001;57(2):43-56.

22. Traber $M G$, Atkinson J. Vitamin $E$, antioxidant and nothing more. Free Radic Biol Med. 2007;43(1):4-15.

23. Lorenzo JM, Munekata PES. Phenolic compounds of green tea: health benefits and technological application in food. Asian Pac J Trop Biomed. 2016;6(8):709-19.

24. Kagaya N, Tagawa Y, Nagashima H, et al. Suppression of cytotoxin-induced cell death in isolated hepatocytes by tea catechins. Eur J Pharmacol. 2002; 450:231-6.

25. Jeong JH, Kim HJ, Lee TJ, et al. Epigallocatechin 3-gallate attenuates neuronal damage induced by 3-hydroxykynurenine. Toxicology. 2004;195:53-60.

26. Levites $Y$, Amit T, Youdim MB, Mandel S. Involvement of protein kinase $C$ activation and cell survival/cell cycle genes in green tea polyphenol (U-epigallocatechin 3gallate neuroprotective action. J Biol Chem. 2002;277:30574-80

27. Du GJ, Zhang Z, Wen XD, Yu C, Calway T, Yuan CS, Wang CZ. Epigallocatechin Gallate (EGCG) is the most effective cancer chemopreventive polyphenol in green tea. Nutrients. 2012;4(11):1679-91. https://doi.org/10.3390/nu4111679.
28. Luthra PM, Singh R, Chandra R. Therapeutic use of Curcumin longa. Ind J Clin Biochem. 2001;16:153-60.

29. Ak T, Gülçin I. Antioxidant and radical scavenging properties of curcumin. Chem Biol Interact. 2008;174:27-37.

30. Shukla PK, Khanna VK, Khan MY. Protective effect of curcumin against lead neurotoxicity in rats. Hum Exp Toxicol. 2003;22:653-8.

31. Eybl V, Kotyzova D, Leseticky L, et al. The influence of curcumin and manganese complex of curcumin on cadmium-induced oxidative damage and trace element status in tissues of mice. J Appl Toxicol. 2006;26:207-21230.

32. Oda Y. Inhibitory effect of curcumin on SOS functions induced by UV irradiation. Mutat Res. 1995;348:67-73.

33. Tiwari T, Rao MV. Curcumin supplementation protects from genotoxic effects of arsenic and fluoride. Food Chem Toxicol. 2010:48:1234-8.

34. Prakash A, Khan S, Kumar D, et al. Concurrent administration of curcumin mitigates arsenic - and chlorpyrifos - induced apoptosis in rat thymocytes. Adv Anim Vet Sci. 2014;7:407-13.

35. Gatz SA, Wiesmuller L. Take a break-resveratrol in action on DNA. Carcinogenesis. 2008;29:321-32.

36. Mehendale $\mathrm{SR}$, Wang $\mathrm{CZ}$, Shao $\mathrm{ZH}$, et al. Chronic pretreatment with American ginseng berry and its polyphenolic constituents attenuate oxidant stress in cardiomyocytes. Eur J Pharmacol. 2006:553:209-14.

37. Du Y, Guo H, Lou H. Grape seed polyphenols protect cardiac cells from apoptosis via induction of endogenous antioxidant enzymes. J Agric Food Chem. 2007:55:1695-701

38. Boyse EA, Miyazawa M, Aoki T, et al. Ly-A and Ly-B: two systems of lymphocyte antigens in the mouse. Proc roy Soc B. 1968;170:175.

39. Hayashi M, Sofuni T, Ishidata MJ. An application of acridine orange fluorescent staining to the micronucleus test. Mutat Res. 1983;120:241-7.

40. Sambrook J, Russel DW. Molecular cloning: a laboratory manual. New York: Cold/Spring Harbor Laboratory Press; 2001. p. A1-A12.

41. Dhawan A, Bajpayee M, Pandey AK, et al. Protocol for the single cell gel electrophoresis/comet assay for rapid genotoxicity assessment. Lucknow: ITRC; 2009. p. 1-10.

42. Shafiq-U-Rehman. Lead-induced regional lipid peroxidation in brain. Toxicol Lett. 1984;21:333-7.

43. Sedlak J, Lindsay RH. Estimation of total protein bound NPSH groups in tissues with Ellaman's reagent. Anal Biochem. 1968;25:192-205.

44. Bergmeyer HU. U.V. method of catalase assay. In: Methods of enzymatic analysis, vol. III. 3rd ed. Weinheim, Dacrfield Beach, Florida, Basal; 1983. p. 273

45. Madesh M, Balasubramanian KA. Microtiter plate assay for superoxide dismutase using MTT reduction by superoxide. Indian J Biochem Biophys. 1998:35:184-8

46. Habig WH, Pabst MJ, Jacokoby WB. Gluuathione-S-transferase: the first enzymatic step in mercapturic acid formation. J Biol Chem. 1974;249:7130-9.

47. Paglia DE, Valantine WN. Studies on the quantitative and qualitative characterization of erythrocyte glutathione peroxidase. J Lab Clin Med. 1967 70:158-69.

48. Lowery $\mathrm{OH}$, Rosenbrough NJ, Farr AL, Randall RJ. Protein measurement with the Folin phenol reagent. J Biol Chem. 1951:193:265-75.

49. Luna LG. Manual of histology staining methods of the armed forces Institute of Pathology. 3rd ed. New York: Mcgraw-Hill Book Co; 1968.

50. International Agency for Research on Cancer. Monographs-cadmium. Lyon: IARC; 2003.

51. Agency for Toxic substance and Disease Registry. Draft Toxicological profile for cadmium. Atlanta: ATSDR; 2007.

52. Segura MEC, Gomez-Arroyo S, Villalobos-Pietrini R, et al. Evaluation of genotoxic and cytotoxic efffects in human peripheral blood lymphocytes exposedi $n$ vitro to neonicotinoid insecticides news. J Toxicology. 2012; 2012:1-11. https://doi.org/10.1155/2012/612647.

53. Bal R, Türk G, Tuzcu M, Yilmaz O, et al. Assessment of imidacloprid toxicity on reproductive organ system of adult male rats. J Envi Sci Health, Part B. 2012:47:434-44

54. Lu J, Yaun-lin Z, Dong-Mei W, et al. Trace amounts of copper induce neurotoxicity in the cholesterol-fed mice through apoptosis. FEBS Lett. 2006;580:6730-40

55. Tufan AC, Akdogan I, Turgut G, et al. Increased Tunel positive cells in CA1, CA2, and CA3 subfields of rat hippocampus due to copper and ethanol coexposure. International J Neurosci. 2008;118:647-56.

56. Lemos AO, Oliviera NCD, Lemos CT. In vitro micronuclei test to evaluate the genotoxicity of surface water under the influence of tanneries. Toxicol in Vitro. 2011;25:761-6. 
57. Garriott ML, Phelps JB, Hoffman WP. A protocol for the in-vitro micronucleus test I. contribution to the development of a protocol suitable for regulatory submissions from an examination of 16 chemicals with different mechanism of action and level of activity. Mutation Res. 2002;517: 123-34.

58. Corvi R, Albertini S, Hartung T, et al. ECVAM retrospective validation of in vitro micronucleus test (MNT). Mutagenesis. 2008;7:1-13.

59. Ali D, Nagpure NS, Kumar S, et al. Assessment of genotoxic and mutagenic effects of chlorpyrifos in freshwater fish Channa punctatus (Bloch) using micronucleus assay and alkaline single-cell gel electrophoresis. Food Chem Toxicol. 2009:47:650-6.

60. Costa C, Silvari V, Melchini A, et al. Genotoxicity of imidacloprid in relation to metabolic activation and composition of the commercial product. Mutat Res-Genet Toxicol Environ Mutagenesis. 2009;672:40-4

61. Bhunya SP, Pati PC. Genotoxicity of an inorganic pesticide, copper sulphate in mouse in vivo test system. Cytologia. 1987;52:801-8.

62. Agarwal K, Sharma A, Talukder G. Clastogenic effects of copper sulfate on the bone marrow chromosomes of mice in vivo. Mutat Res. 1990;243:1-6.

63. Cavas T, Garanko NN, Arkhipchuk W. Induction of micronuclei and binuclei in blood, gill and liver cells of fishes subchronically exposed to cadmium chloride and copper sulphate. Food Chem Toxicol. 2005:43:569-74.

64. Bhunya SP, Jena GB. Clastogenic effect of copper sulphate in chick in vivo test system. Mutat Res. 1996:367:57-63.

65. Fairbairn DW, Olive PL, O'Neil KL. The comet assay comprehensive review. Mutat Res. 1995:399:32-59.

66. Mitchelmore $\mathrm{CL}$, Chipman JK. DNA strand breakage in aquatic organisms and the potential value of the comet assay in environmental monitoring Mutat Res. 1998;399:135-47.

67. Singh RP, Kumar S, Nada R, et al. Evaluation of Cu toxicity in isolated human peripheral blood mononuclear cells and it's attenuation by zinc: Ex Vivo. Mol Cell Biochem. 2006;282:13-21.

68. Vidyashankar S, Patki PS. Liv.52 attenuate copper induced toxicity by inhibiting glutathione depletion and increased antioxidant enzyme activity in HepG2 cells. Food Chem Toxicol. 2010;48:1863-8.

69. Halliwell B, Gutteridge JMC. Free radicals, other reactive species in: free radicals in biology and Madicine. Oxford: Oxford University Press; 1999. p. 617-783.

70. Lieber CS. S-Adenosyl-L-methionine and alcoholic liver disease in animal models: implications for early intervention in human beings. Alcohol. 2002; 27:173-7.

71. Hung YC, Sava VM, Blagodarsky VA, et al. Protection of tea melanin on hydrazineinduced liver injury. Life Sci. 2003;72:1061-71.

72. Ookhtens $M$, Kaplowitz $N$. Role of the liver in interorgan homeostasis of glutathione and cyst(e)ine. Semin Liver Dis. 1998;18:313-29.

73. Mahboob M, Siddiqui MK. Alteration in hepatic detoxifying enzymes by new organophosphorous insecticides following subchronic exposure in rats. JAppl Toxicol. 2001;21:5015-505.

74. Hayes JD, Pulford D. The glutathione- S-transferase supergene family: regulation of GST and the contribution of the isoenzymes to cancer chemoprotection and drug resistance. Crit Rev Biochem Mol Biol. 1995;30: 445-600.

75. Josephy PD. Genetic variations in human glutathione transferase enzymes: significance for pharmacology and toxicology. Hum. Genomics Proteomics 2010;2010:876940-876953.1-14. https://doi.org/10.4061/2010/876940.

76. Halliwell B, Gutteridge JMC. Free radicals in biology and medicine. 4th ed. Oxford: Clarendon Press; 2001.

77. Kadiiska MB, Hanna PM, Jordan SJ, Mason RP. Electron spin resonance for free radical generation in copper-treated vitamin-E and selenium-deficient rats: in vivo spin-trapping investigation. Mol Pharmacol. 1993:44:222-7.

78. Bremner I. Manifestations of copper excess. Am J Clin Nutr. 1998;67:1069S735.

79. Pourahmad J, O'Brien PJ. A comparison of hepatocytes cytotoxic mechanisms for $\mathrm{Cu}^{-2}$ and $\mathrm{Cd}-2$. Toxicology. 2000;143:263-73.

80. Kawanishi S, Inoe S, Yamamoto K. Hydroxyl radical and singlet oxygen production and DNA damage induced by carcinogenic metal compounds and hydrogen peroxide. Biol Trace Elem Res. 1989;21:367-72.

81. Mattie MD, Freedman JH. Protective effects of aspirin and vitamin E (alphatocopherol) against copper and cadmium-induced toxicity. Biochem Biophys Res Commun. 2001;285:921-5.
82. Sarkar A, Das J, Manna P, Sil PC. Nano copper induces oxidative stress and apoptosis in kidney via both extrinsic and intrinsic pathways. Toxicol. 2011; 290:208-17.

83. Cao Z, Li Y. Potent induction of cellular antioxidants and phase 2 enzymes by resveratrol in cardiomyocytes: protection against oxidative and electrophilic injury. Eur J Pharmacol. 2004;489:39-48.

84. Wu MX, Ao Z, Prasad KV, Wu R, Schlossman SF. Science. 1998;281:998-1001.

85. Upadhyay G, Singh AK, Kumar A, Prakash O, Singh MP. Resveratrol modulates pyrogallol-induced changes in hepatic toxicity markers, xenobiotic metabolizing enzymes and oxidative stress. Eur J Pharmacol. 2008:596(1-3):146-52.

86. Kashima M. Effects of catechins on superoxide and hydroxyl radical. Chem Pharm Bull. 1999:47:279-83.

87. Seeram NP, Nair MG. Inhibition of lipid peroxidation and structure-activityrelated studies of the dietary constituents anthocyanins, anthocyanidins, and catechins. J Agric Food Chem. 2002;50:5308-12.

88. Ogaly HA, Khalaf AA, Ibrahim MA, Galal MK, Abd-Elsalam RM. Influence of green tea extract on oxidative damage and apoptosis induced by deltamethrin in rat brain. Neurotoxicol Teratol. 2015;50:23-31.

89. Jagetia GC. Radioprotection and radiosensitization by curcumin. Adv Exp Med Biol. 2007;595:301-20.

90. Masuda T, Maekawa T, Hidaka K, Bando H, Takeda Y, Yamaguchi H. Chemical studies on antioxidant mechanisms of curcumin: analysis of oxidative coupling products from curcumin and linoleate. J Agric Food Chem. 2001;49:2539-47.

91. Sreejayan N, Rao MN. Curcuminoids as potent inhibitors of lipid peroxidation. J Pharm Pharmacol. 1994;46:1013-6.

92. Gutteridge JM, Halliwell B. Free radicals and antioxidants in the year 2000. A historical look to the future. Ann NY Acad Sci. 2000;899:136-47.

93. Chan MM, Huang HI, Fenton MR, Fong D. In vivo inhibition of nitric oxide synthase gene expression by curcumin, a cancer preventive natural product with anti-inflammatory properties. Biochem Pharmacol. 1998;55:1955-62.

94. Bisby $\mathrm{RH}$, Johnson SA, Parker AW. Quenching of reactive oxidative species by probucol and comparison with other antioxidants. Free Radic Biol Med. 1996:20:411-20.

95. Kalender S, Kalender Y, Ogutcu A, Uzunhisarcikli M, Durak D, Acikgoz F. Endosulfan-induced cardiotoxicity and free radical metabolism in rats: the protective effect of vitamin E. Toxicology. 2004;202:227-35.

96. Mandil R, Rahal A, Prakash A, Garg SK, Gangwar NK, Swain DK. Ameliorative potential of a-tocopherol against flubendiamide and copper-induced testicular-insult in Wistar rats. Chem Biol Interact. 2016;260:91-101.

97. Sharma RK, Sharma B. In-vitro carbofuran induced genotoxicity in human lymphocytes and its mitigation by vitamins C and E. Dis Markers. 2012;32: $153-63$

\section{Publisher's Note}

Springer Nature remains neutral with regard to jurisdictional claims in published maps and institutional affiliations.

Ready to submit your research? Choose BMC and benefit from:

- fast, convenient online submission

- thorough peer review by experienced researchers in your field

- rapid publication on acceptance

- support for research data, including large and complex data types

- gold Open Access which fosters wider collaboration and increased citations

- maximum visibility for your research: over $100 \mathrm{M}$ website views per year

At BMC, research is always in progress.

Learn more biomedcentral.com/submissions 